\title{
Genetic Factors Associated with Prostate Cancer
}

4 Yu Jiang, ${ }^{1,41}$ Travis J. Meyers, ${ }^{1,41}$ Adaeze A. Emeka, ${ }^{2}$ Lauren Folgosa Cooley, ${ }^{2}$ Phillip R.

5 Cooper, ${ }^{2}$ Nicola Lancki, ${ }^{3}$ Irene Helenowski, ${ }^{3}$ Linda Kachuri, ${ }^{1}$ Daniel W. Lin, ${ }^{4,5}$ Janet L.

6 Stanford, ${ }^{6,7}$ Lisa F. Newcomb, ${ }^{4,5}$ Suzanne Kolb, ${ }^{6,7}$ Antonio Finelli, ${ }^{8}$ Neil E. Fleshner, ${ }^{8}$ Maria

7 Komisarenko, ${ }^{8}$ James A. Eastham, ${ }^{9}$ Behfar Ehdaie, ${ }^{9}$ Nicole Benfante, ${ }^{9}$ Christopher J.

8 Logothetis, ${ }^{10}$ Justin R. Gregg, ${ }^{10}$ Cherie A. Perez, ${ }^{10}$ Sergio Garza, ${ }^{10}$ Jeri Kim, ${ }^{10}$ Leonard S.

9 Marks, ${ }^{11}$ Merdie Delfin, ${ }^{11}$ Danielle Barsa, ${ }^{11}$ Danny Vesprini, ${ }^{12}$ Laurence H. Klotz, ${ }^{12}$ Andrew

10 Loblaw, ${ }^{12}$ Alexandre Mamedov, ${ }^{12}$ S. Larry Goldenberg, ${ }^{13}$ Celestia S. Higano, ${ }^{13}$ Maria Spillane, ${ }^{13}$

11 Eugenia Wu, ${ }^{13} \mathrm{H}$. Ballentine Carter, ${ }^{14}$ Christian P. Pavlovich, ${ }^{14}$ Mufaddal Mamawala, ${ }^{14}$ Tricia

12 Landis, ${ }^{14}$ Peter R. Carroll, ${ }^{15}$ June M. Chan, ${ }^{1,15}$ Matthew R. Cooperberg, ${ }^{15,16}$ Janet E. Cowan, ${ }^{15}$

13 Todd M. Morgan, ${ }^{17}$ Javed Siddiqui, ${ }^{18}$ Rabia Martin, ${ }^{18}$ Eric A. Klein, ${ }^{19}$ Karen Brittain, ${ }^{19}$ Paige

14 Gotwald, ${ }^{19}$ Daniel A. Barocas, ${ }^{20}$ Jeremiah R. Dallmer, ${ }^{20,21}$ Jennifer B. Gordetsky, ${ }^{20,22}$ Pam

15 Steele, ${ }^{20}$ Shilajit D. Kundu, ${ }^{2}$ Jazmine Stockdale, ${ }^{2}$ Monique J. Roobol, ${ }^{23}$ Lionne D.F.

16 Venderbos, ${ }^{23}$ Martin G. Sanda, ${ }^{24}$ Rebecca Arnold, ${ }^{24}$ Dattatraya Patil, ${ }^{24}$ Christopher P. Evans, ${ }^{25}$

17 Marc A. Dall'Era, ${ }^{25}$ Anjali Vij, ${ }^{25}$ Anthony J. Costello, ${ }^{26}$ Ken Chow,${ }^{26}$ Niall M. Corcoran, ${ }^{26}$ Soroush

18 Rais-Bahrami, ${ }^{27,28}$ Courtney Phares, ${ }^{27}$ Douglas S. Scherr, ${ }^{29}$ Thomas Flynn, ${ }^{29}$ R. Jeffrey

19 Karnes, ${ }^{30}$ Michael Koch, ${ }^{31}$ Courtney Rose Dhondt, ${ }^{31}$ Joel B. Nelson, ${ }^{32}$ Dawn McBride,${ }^{32}$ Michael

20 S. Cookson, ${ }^{33}$ Kelly L. Stratton, ${ }^{33}$ Stephen Farriester, ${ }^{33}$ Erin Hemken, ${ }^{33}$ Walter M. Stadler, ${ }^{34}$

21 Tuula Pera, ${ }^{34}$ Deimante Banionyte, ${ }^{34}$ Fernando J. Bianco Jr. ${ }^{35}$ Isabel H. Lopez, ${ }^{35}$ Stacy Loeb, ${ }^{36}$

22 Samir S. Taneja, ${ }^{36}$ Nataliya Byrne,${ }^{36}$ Christopher L. Amling, ${ }^{37}$ Ann Martinez, ${ }^{37}$ Luc Boileau, ${ }^{37}$

23 Franklin D. Gaylis, ${ }^{38}$ Jacqueline Petkewicz, ${ }^{39}$ Nicholas Kirwen, ${ }^{39}$ Brian T. Helfand, ${ }^{39}$ Jianfeng

$24 \mathrm{Xu},{ }^{39}$ Denise M. Scholtens, ${ }^{3}$ William J. Catalona, ${ }^{2,42}$ John S. Witte ${ }^{1,15,16,40,42}$

Author Affiliations: 
medRxiv preprint doi: https://doi.org/10.1101/2021.08.30.21262305; this version posted August 31, 2021. The copyright holder for this preprint (which was not certified by peer review) is the author/funder, who has granted medRxiv a license to display the preprint in perpetuity.

All rights reserved. No reuse allowed without permission.

$27{ }^{1}$ Department of Epidemiology and Biostatistics, University of California, San Francisco, San Francisco, CA 2894158, USA

29 2Department of Urology, Northwestern University Feinberg School of Medicine, Chicago, IL 60611, USA

$30{ }^{3}$ Division of Biostatistics, Department of Preventive Medicine, Northwestern University Feinberg School of

31 Medicine, Chicago, IL 60611, USA

$32{ }^{4}$ Fred Hutchinson Cancer Research Center, Cancer Prevention Program, Public Health Sciences, Seattle, 33 WA 98109, USA

$34{ }^{5}$ Department of Urology, University of Washington, Seattle 98195, WA, USA

$35{ }^{6}$ Fred Hutchinson Cancer Research Center, Cancer Epidemiology Program, Public Health Sciences,

36 Seattle, WA 98109, USA

$37{ }^{7}$ Department of Epidemiology, University of Washington, School of Public Health, Seattle, WA 98195, USA

$38{ }^{8}$ Division of Urology, Department of Surgery, Princess Margaret Cancer Centre, University Health Network,

39 Toronto, Ontario, Canada

$40{ }^{9}$ Urology Service, Department of Surgery, Memorial Sloan Kettering Cancer Center, New York, NY, USA

$41{ }^{10}$ Departments of Genitourinary Medical Oncology and Urology, University of Texas M.D. Anderson Cancer

42 Center, Houston, TX, USA

$43{ }^{11}$ Department of Urology, David Geffen School of Medicine at UCLA, USA

$44{ }^{12}$ Odette Cancer Centre, Sunnybrook Health and Sciences Centre, University of Toronto, Toronto, ON,

45 Canada

$46{ }^{13}$ Department of Urologic Sciences, University of British Columbia, Vancouver, BC, Canada

$47{ }^{14}$ Brady Urological Institute, Johns Hopkins University School of Medicine, Baltimore, MD, USA

$48{ }^{15}$ Department of Urology, University of California, San Francisco, San Francisco, CA, USA

$49{ }^{16}$ Helen Diller Family Comprehensive Cancer Center, University of California, San Francisco, San

50 Francisco, CA, USA

$51{ }^{17}$ Department of Urology, University of Michigan, Ann Arbor, MI, USA

$52{ }^{18}$ Department of Pathology, University of Michigan, Ann Arbor, MI, USA

$53{ }^{19}$ Glickman Urological and Kidney Institute, Cleveland Clinic Lerner College of Medicine, Cleveland Clinic, 54 USA 
medRxiv preprint doi: https://doi.org/10.1101/2021.08.30.21262305; this version posted August 31, 2021. The copyright holder for this preprint (which was not certified by peer review) is the author/funder, who has granted medRxiv a license to display the preprint in perpetuity.

All rights reserved. No reuse allowed without permission.

$55{ }^{20}$ Department of Urology, Vanderbilt University Medical Center, Nashville, TN, USA

$56{ }^{21}$ Department of Urology, Cedars-Sinai Medical Center, Los Angeles, CA, USA

57 22Department of Pathology, Microbiology, and Immunology, Vanderbilt University Medical Center, Nashville,

58 TN, USA

$59{ }^{23}$ Department of Urology, Erasmus Cancer Institute, Erasmus University Medical Center, Rotterdam, the

60 Netherlands

$61{ }^{24}$ Department of Urology, Emory University School of Medicine, Atlanta, GA, USA

$62{ }^{25}$ Department of Urologic Surgery, University of California, Davis Medical Center, Sacramento, CA, USA

$63{ }^{26}$ Department of Urology, Royal Melbourne Hospital and University of Melbourne, Australia

$64{ }^{27}$ Department of Urology, University of Alabama at Birmingham, Birmingham, AL, USA

$65{ }^{28}$ Department of Radiology, University of Alabama at Birmingham, Birmingham, AL, USA

$66{ }^{29}$ Department of Urology, Weill Cornell Medicine, New York-Presbyterian Hospital, New York, NY, USA

$67{ }^{30}$ Mayo Clinic Department of Urology, Rochester, MN, USA

$68{ }^{31}$ Department of Urology, Indiana University School of Medicine, Indianapolis, IN, USA

$69{ }^{32}$ Department of Urology, University of Pittsburgh School of Medicine, PA, USA

$70{ }^{33}$ Department of Urology, University of Oklahoma Health Sciences Center, Oklahoma City, OK, USA

$71{ }^{34}$ University of Chicago Comprehensive Cancer Center, Chicago, IL, USA

$72{ }^{35}$ Urological Research Network, Miami Lakes, FL, USA

$73{ }^{36}$ Departments of Urology and Population Health, New York University Langone Health and Manhattan

74 Veterans Affairs Medical Center, New York, NY, USA

$75{ }^{37}$ Department of Urology, Oregon Health and Science University, Portland, OR, USA

$76{ }^{38}$ Genesis Healthcare Partners, Department of Urology, University of California, San Diego, CA, USA

$77{ }^{39}$ Division of Urology, NorthShore University Health System, Evanston, IL, USA

$78{ }^{40}$ Departments of Epidemiology and Population Health, Biomedical Data Science, and Genetics, Stanford

79 University, Stanford, CA, USA

$80{ }^{41}$ These authors contributed equally to the first authorship.

$81{ }^{42}$ These authors contributed equally to the senior authorship. 
medRxiv preprint doi: https://doi.org/10.1101/2021.08.30.21262305; this version posted August 31, 2021. The copyright holder for this preprint (which was not certified by peer review) is the author/funder, who has granted medRxiv a license to display the preprint in perpetuity.

All rights reserved. No reuse allowed without permission.

83 Correspondence to John S. Witte (jswitte@stanford.edu)

84

85 Descriptive running head: Genetics of prostate cancer conversion from active surveillance

86 Keywords (MeSH Headings): prostatic neoplasms; prostate; genome-wide association study,

87 genetics

88 Support: NIH grant P50CA180995; CIDR Contract \# HHSN268201700006I 
medRxiv preprint doi: https://doi.org/10.1101/2021.08.30.21262305; this version posted August 31, 2021. The copyright holder for this preprint (which was not certified by peer review) is the author/funder, who has granted medRxiv a license to display the preprint in perpetuity.

All rights reserved. No reuse allowed without permission.

\section{Abstract}

Men diagnosed with low-risk prostate cancer (PC) are increasingly electing active surveillance

91 (AS) as their initial management strategy. While this may reduce the side effects of treatment for

92 prostate cancer, many men on AS eventually convert to active treatment. PC is one of the most

93 heritable cancers, and genetic factors that predispose to aggressive tumors may help

94 distinguish men who are more likely to discontinue AS. To investigate this, we undertook a

95 multi-institutional genome-wide association study (GWAS) of 6,361 PC patients who initially

96 elected AS and were followed over time for the potential outcome of conversion from AS to

97 active treatment. In the GWAS we detected 18 single nucleotide polymorphisms (SNPs) associated with conversion, 15 of which were not previously associated with PC risk. We found two genes associated with conversion (MAST3, $p=6.9 \times 10^{-7}$ and $G A B 2, p=2.0 \times 10^{-6}$ ). Moreover, increasing values of a previously validated 269-SNP genetic risk score (GRS) for PC was positively associated with conversion (e.g., comparing the highest to the two middle deciles gave a hazard ratio $[H R]=1.13 ; 95 \%$ Confidence Interval $[\mathrm{Cl}]=0.94-1.36)$; whereas, decreasing values of a 36-variant GRS for prostate-specific antigen (PSA) levels were positively associated

104 with conversion (e.g., comparing the lowest to the two middle deciles gave a HR $=1.25 ; 95 \%$

$105 \mathrm{Cl}, 1.04-1.50)$. These results suggest that germline genetics may help inform and individualize

106 the decision of AS—or the intensity of monitoring on AS-versus treatment for the initial

107 management of patients with low-risk PC. 
medRxiv preprint doi: https://doi.org/10.1101/2021.08.30.21262305; this version posted August 31, 2021. The copyright holder for this preprint (which was not certified by peer review) is the author/funder, who has granted medRxiv a license to display the preprint in perpetuity.

All rights reserved. No reuse allowed without permission.

\section{Introduction}

109 Active surveillance (AS) is now more widely implemented as an initial management strategy for 110 many men with lower-risk prostate cancer (PC [MIM: 176807]) ${ }^{1}$. PC that is unlikely to invade 111 surrounding tissue or metastasize according to characteristics at diagnosis is considered "low-

112 risk" or "favorable-intermediate risk"2. Recent work in the United States Veterans Administration

113 (VA) Health Care System ${ }^{3,4}$ and in Sweden ${ }^{5}$ indicates that a majority of men with low-risk PC

114 are being managed with AS. Determining which patients most benefit from early active

115 treatment versus AS, however, and how intensive the surveillance protocol should be, remains 116 a challenge.

A major drawback of AS for low-risk PC is the possibility of misclassifying patients with lifethreatening disease. In fact, over a 10 -year follow-up period, $20-40 \%$ of men initially managed with AS later have more aggressive cancer ${ }^{6}$. While the impact of delayed treatment is unknown,

121 up to $50 \%$ of men in one AS series of studies experienced biochemical recurrence after active

122 treatment $^{7}$. These uncertainties and challenges in accurately discriminating between indolent

123 and aggressive PC may prompt men to err on the side of early treatment resulting in

124 unnecessary side effects and worse health-related quality of life, or conversely result in delays

125 in therapy for men who are likely to benefit from it. Many men have such low-risk disease that

126 they do not need the biopsies or scans with the frequency with which they have typically been

127 performed. Recent work suggests that the likelihood of risk reclassification of an individual

128 patient's disease might be predicted for at least four years of $\mathrm{AS}^{8}$. Thus, it may be possible

129 reduce the intensity of surveillance for many men with the lowest-risk tumors.

131 A key outstanding question is how to best distinguish among low- and high-risk tumors for AS

132 decisions. Promising recent developments for enhancing clinical risk assessment include multi133 parametric MRI with targeted prostate biopsy and tissue-based genomic testing ${ }^{9,10}$. Another 
medRxiv preprint doi: https://doi.org/10.1101/2021.08.30.21262305; this version posted August 31, 2021. The copyright holder for this preprint (which was not certified by peer review) is the author/funder, who has granted medRxiv a license to display the preprint in perpetuity.

All rights reserved. No reuse allowed without permission.

134 potentially valuable approach is incorporating germline genetic information for PC via a

135 polygenic risk score ${ }^{11}$. PC is one of the most heritable of common cancers, with germline

136 genetic factors accounting for over $40 \%$ of the variability in this disease ${ }^{12-15}$. We and others

137 have identified from genome-wide association studies (GWAS) 269 common germline genetic

138 variants associated with PC susceptibility that explain a substantial proportion of disease

139 heritability ${ }^{16-43}$. Combining these PC risk variants together into a genetic risk score (GRS) may

140 provide a more discriminatory biomarker not only for PC risk, but also potentially for predicting

141 conversion from AS to treatment ${ }^{44-47}$. Moreover, we recently have discovered genetic variants

142 that explain variability in PSA levels ${ }^{48}$. Since PSA is a critical component to monitoring men

143 undergoing AS, incorporating this information may also help to identify ideal AS candidates.

145 To evaluate the potential value of incorporating germline genetic information into the shared decision-making process for AS, we present findings from a large, multi-institutional GWAS of

147 men diagnosed with PC enrolled in an AS program. We report novel variants and genes, and 148 genetic risk scores associated with conversion from AS to treatment.

\section{Material and Methods}

151 Participants

152 The primary study participants came from 28 institutions in the US, Canada, the Netherlands, 153 and Australia. We recently reported on the clinicopathological characteristics of conversion to 154 treatment in this population ${ }^{49}$. The initial study population included 7,279 men diagnosed with 155 PC between 1991 and 2018 who elected AS for their initial management. We also included an 156 additional 593 AS patients from the University of Texas MD Anderson Cancer Center as 157 replication samples, described below. Patients' blood or tissue samples were collected to 158 conduct germline genetic analyses. The AS protocols varied among participating institutions, 159 reflecting real-world practice patterns ${ }^{50-53}$, and we did not impose strict inclusion/exclusion 
medRxiv preprint doi: https://doi.org/10.1101/2021.08.30.21262305; this version posted August 31, 2021. The copyright holder for this preprint (which was not certified by peer review) is the author/funder, who has granted medRxiv a license to display the preprint in perpetuity.

All rights reserved. No reuse allowed without permission.

criteria based on the AS protocol. Patient demographic and clinical variables were collected and

161 managed using the Research Electronic Data Capture (REDCap) software ${ }^{54,55}$. Men without

162 data on the duration of $\mathrm{AS}(235,3.2 \%)$ and those managed with AS for less than six months

$163(269,3.7 \%)$ were excluded, leaving 6,775 men for potential inclusion in the GWAS. This study

164 was approved by the institutional review board at each institution, all participants provided

165 written informed consent, and all participating institutions signed a material transfer and data

166 use agreement.

Clinical and Demographic Factors

We collected PC characteristics at diagnosis, including the age at diagnosis, Gleason grade group (GG), PSA level, clinical tumor stage (cT), and the number of cancerous biopsy cores at

171 diagnosis. Grade groups correspond to the following Gleason scores (GS): GG1 GS $\leq 6$; GG2

$172 \sim$ GS 3+4; GG3 GS 4+3; GG4 GS 8; GS $5 \sim$ GS 9 or $10^{56}$. Study participants were classified

173 into three risk groups (low-, intermediate-, and high-risk) based on our modification of guidelines

174 from the National Comprehensive Cancer Network (NCCN) and the American Urological

175 Association (AUA). We did not strictly follow these guidelines because we were unable to

176 distinguish between cT2a, cT2b, and cT2c, and we did not have data on PSA density (serum

177 PSA concentration divided by prostate volume). Therefore, low-risk patients met the following

178 criteria: Gleason grade group 1 (GG1) (Gleason score 3+3), PSA <10 ng/mL, clinical-stage cT1,

179 and $\leq 3$ positive biopsy cores. Intermediate-risk patients had any of the following without any

180 high-risk or high-volume criteria: GG2 (Gleason 3+4), PSA 10-20 ng/mL, or stage cT2. High-risk

181 patients had any of the following: $\geq$ GG3 ( $\geq$ Gleason $4+3$ ), PSA $\geq 20 \mathrm{ng} / \mathrm{mL}$, stage $\geq c T 3$, or $\geq 4$

182 positive biopsy cores of any GG.

184 Conversion occurred when a patient received treatment following AS. The reason for 185 withdrawing from AS to begin treatment was reported as due to "upgrading", "upstaging", "PSA 
medRxiv preprint doi: https://doi.org/10.1101/2021.08.30.21262305; this version posted August 31, 2021. The copyright holder for this preprint (which was not certified by peer review) is the author/funder, who has granted medRxiv a license to display the preprint in perpetuity.

All rights reserved. No reuse allowed without permission.

186 progression", "anxiety", and/or "other" reasons. Note that in our survival analysis (below),

187 individuals who converted due to anxiety were censored and do not contribute events in our

188 analysis. We used the ADMIXTURE software program to infer genetic ancestry from

189 uncorrelated SNPs, according to major reference populations in the 1000 Genomes Project

190 (European, African, East/South Asian combined, and Admixed American) ${ }^{57}$.

\section{Genotyping and Imputation}

193 In total, 6,324 participants were genotyped on the Illumina Infinium Multi-Ethnic Global Array

194 (MEGA), including custom content, at the NIH Center for Inherited Disease Research (CIDR) at

195 Johns Hopkins University. Genotypes were called using GenomeStudio version 2011.1,

196 Genotyping Module version 1.9.4, and GenTrain Version 1.0. The full array with custom content 197 consisted of $1,760,143$ SNPs.

After genotyping, the median SNP call rate was $99.94 \%$, and the error rate estimated from 122 pairs of planned study duplicates was $1.3 \times 10^{-6}$. Samples and variants were excluded if they had a sample or genotyping call rate $<98 \%$. We limited our analyses to variants with a minor allele frequency $(\mathrm{MAF}) \geq 1 \%$. Variants were screened for deviations from Hardy-Weinberg equilibrium with a filter threshold of $p=6.5 \times 10^{-4}$. A total of 856,077 genotyped SNPs remained after these quality control (QC) steps. Unmeasured genetic variants were imputed using the Trans-Omics for Precision Medicine (TOPMed) Imputation Server, with 97,256 reference samples and $308,107,085$ SNPs. Variants with imputation quality (INFO) score $<0.3$ were excluded, leaving

207 a total of 22,691,641 SNPs successfully imputed. After QC steps, a total of 5,936 samples

208 genotyped at CIDR remained for inclusion in the GWAS.

210 Furthermore, we included in our analysis an additional 593 AS patients from MD Anderson 211 previously genotyped on the Illumina Infinium OncoArray-500K BeadChip Array. This array was 
medRxiv preprint doi: https://doi.org/10.1101/2021.08.30.21262305; this version posted August 31, 2021. The copyright holder for this preprint (which was not certified by peer review) is the author/funder, who has granted medRxiv a license to display the preprint in perpetuity.

All rights reserved. No reuse allowed without permission.

212 primarily developed to study cancer predisposition and risk. Genotypes were called using

213 GenomeStudio version 2011.1. The full array consisted of 500,000 SNPs. Genotype QC

214 procedures and imputation for the PRACTICAL OncoArray have been described previously ${ }^{15}$.

215 Briefly, imputation was performed without pre-phasing with SHAPEIT2 based on the 1000

216 Genomes Phase 3 release reference panel. In total, 21,299,194 SNPs were successfully

217 imputed, and 10,109,977 variants with MAF $\geq 1 \%$ on autosomal chromosomes 1-22 and sex

218 chromosome X.

219

220 GWAS of Conversion from AS to Treatment

221 The variants with MAF $\geq 1 \%$ on autosomal chromosomes 1-22 and sex chromosome $\mathrm{X}$ were

222 tested for their association with time to conversion from AS to treatment among the 5,222 men

223 of European genetic ancestry genotyped by CIDR. Patients who converted due to anxiety were

224 censored because the event of interest was converting due to a change in the cancer clinical

225 characteristics. Per-allele hazard ratios (HRs), 95\% confidence intervals (Cls), and

226 corresponding p-values were calculated from Cox proportional hazards models. HRs were

227 adjusted for age at diagnosis and the first 10 genetic principal components to address potential

228 population stratification or cryptic relatedness. Adjusted HRs were calculated using the

229 gwasurvivr package in $\mathrm{R}^{58}$. For any variants associated with conversion, we examined the Cox

230 models' proportional hazards assumption.

232 Following the GWAS discovery phase, the potential associations were tested for replication in

233 an independent GWAS among 1,139 men also genotyped by CIDR (but of non-European

234 ancestry) and the 425 MD Anderson samples of European genetic ancestry (excluding other

235 ancestries). Again, variants with $\mathrm{MAF} \geq 1 \%$ on autosomal chromosomes and sex chromosome

$236 \mathrm{X}$ were tested for their association with conversion within major ancestral populations (i.e.,

237 European, African, Asian, and Admixed American). For the MD Anderson patients, 9,962,324 
medRxiv preprint doi: https://doi.org/10.1101/2021.08.30.21262305; this version posted August 31, 2021. The copyright holder for this preprint (which was not certified by peer review) is the author/funder, who has granted medRxiv a license to display the preprint in perpetuity.

All rights reserved. No reuse allowed without permission.

\section{Genetic Risk Scores}

Genetic risk scores (GRS) were constructed by summing variant-specific weighted allelic dosages for the samples genotyped by CIDR. The initial GRS included the 269 PC risk variants reported in the largest trans-ancestry GWAS meta-analysis of $\mathrm{PC}^{43}$. Specifically, for patient $i$, $G R S_{i}=\sum_{m=1}^{M} w_{m} g_{i m}$, where $g_{i m}$ is the genotype dosage for patient $i$, and variant $m$, and $w_{m}$ is

variants were tested in a Cox proportional hazards model adjusted for age at PC diagnosis and ancestry principal components.

Results from the GWAS were combined with a fixed-effects inverse-variance-weighted metaanalysis using METAL ${ }^{59}$. All statistical tests were two-sided. Marginal $P$ values less than $5 \times 10^{-8}$ were considered statistically significant. We defined a locus as the 1 megabase $(\mathrm{Mb})$ region surrounding the sentinel variant (500 kilobase pairs flanking each side). To identify independently associated variants, within each $1 \mathrm{Mb}$ region we performed clumping on the association results using PLINK v1.9 using a linkage disequilibrium threshold $\left.r^{2}<0.5\right)$.

\section{Transcriptome-Wide Association Study of Conversion from AS to Treatment}

To identify additional genes associated with time to conversion, we conducted a transcriptomewide association analysis (TWAS), which models genetically imputed transcript levels and has a lower multiple testing burden compared to single-variant analysis. We applied the MetaXcan analytic pipeline to our GWAS summary statistics and associated genetically predicted expression of approximately 22,000 genes across 49 issue reference datasets from GTEx $(\text { version } 8)^{60}$. Tissue-specific associations were aggregated using S-MultiXcan to obtain crosstissue $p$-values for each gene ${ }^{60}$. Associations were considered statistically significant at the Bonferroni-corrected alpha level of $2.2 \times 10^{-6}$ (i.e., $0.05 / 22,535$ genes). 
medRxiv preprint doi: https://doi.org/10.1101/2021.08.30.21262305; this version posted August 31, 2021. The copyright holder for this preprint (which was not certified by peer review) is the author/funder, who has granted medRxiv a license to display the preprint in perpetuity.

All rights reserved. No reuse allowed without permission.

264

265

266

267

268

269

270

271

272

273

274

275

276

277

278

279

280

281

282

283

284

285

286

287

288

289

analysis for the GRSPC). $M$ is the total number of variants included in the GRS (M = 269 for the $\left.\mathrm{GRS}_{\mathrm{PC}}\right)$. A second GRS was developed for the genetic basis of serum PSA levels. This GRSPSA included 36 variants and their corresponding weights from a GWAS of PSA levels among cancer-free men. ${ }^{48}$ The associations between these GRS and conversion were estimated using multivariable Cox proportional hazards models. Minimally adjusted Cox models included age and the first 10 genetic principal components. Fully adjusted Cox models also included Gleason grade group (GG1, GG2, or $\geq$ GG3); PSA concentration (ng/mL); clinical stage (cT1, cT2, or cT3/cT4); and number of positive biopsy cores (1-2, 3, or $\geq 4)$. The GRS was modeled as a categorical variable according to deciles of the distribution, and HRs for each decile were estimated with the 40-60th percentile group as the reference.

\section{Clinical Utility of the GRS}

The potential utility of the GRS was evaluated by comparing how the top and bottom deciles of the GRS distribution modified conversion rates within the three PC clinicopathological risk categories (i.e., low-, intermediate-, and high-). For the top and bottom GRS deciles (top $10^{\text {th }}$ percentile and bottom $10^{\text {th }}$ percentile, respectively) we plotted Kaplan-Meier curves of conversion within each PC clinicopathological risk category and tested the difference between each pair of curves with the log-rank test.

To evaluate the overall discriminative capacity of the GRS (i.e., not just the decile tails), we calculated the area under the ROC Curve (AUC) in the discovery sample using regression models of time to conversion. We used Chambless and Diao's estimator of cumulative AUC for right-censored time-to-event data, which is a summary measure given by the integral of AUC on $[0, \max ($ times $)]$ weighted by the estimated probability density of the time-to-event outcome ${ }^{61} . \mathrm{A}$ baseline AUC was calculated for the model that included age and the first 10 principal components. This model was then expanded to further include PC clinical characteristics listed 
medRxiv preprint doi: https://doi.org/10.1101/2021.08.30.21262305; this version posted August 31, 2021. The copyright holder for this preprint (which was not certified by peer review) is the author/funder, who has granted medRxiv a license to display the preprint in perpetuity.

All rights reserved. No reuse allowed without permission.

290 above for the multivariable Cox model, followed by GRSPC and GRSPSA (individually and

291 together).

292

293 Results

294 Study Population

295 Details of the discovery and replication samples that met inclusion criteria are presented in

296 Table S1. Clinically, most men had low-risk PC $(3,639,70 \%)$ and/or features of low-risk, low-

297 volume disease: GG1 (4,819, 92\%), 1-2 positive biopsy cores $(4,113,79 \%)$, and a median PSA

298 at diagnosis of $5 \mathrm{ng} / \mathrm{mL}$. Using genetic information to infer ancestry, $88 \%$ were classified as

299 European ancestry. The demographic and clinicopathological characteristics of the replication

300 samples had a similar pattern as the discovery samples, except that the proportion of high-risk

301 PC was higher for men of Asian genetic ancestry $(n=43 ; 18 \%)$ than of European ancestry $(n=$

$302599 ; 11 \%)$; Table S1). Baseline characteristics were missing for the following proportion of

303 study participants: age at diagnosis (<0.1\%), GG group (<0.1\%), PSA concentration $(3.3 \%)$,

304 clinical tumor stage (6.9\%), number of positive biopsy cores (2.5\%), and risk-group classification

$305(<0.1 \%)$.

306

307 Genome-Wide Association Study of Conversion from AS to Treatment

308 Our approach to the GWAS discovery, replication, and meta-analysis is outlined in Figure 1.

309 The median follow-up time for patients in this multicenter study was 6.7 years. Of the 2,260

310 patients who converted from AS to treatment, $126(5.6 \%)$ converted due to anxiety and were

311 censored in our time-to-event analyses. Our primary discovery GWAS yielded 14 independent

312 lead SNPs (i.e., p-value $<5 \times 10^{-8}$ at each locus of size $1 \mathrm{Mb}$ ) (Figure $2 \mathrm{a}$ ). We replicated 1 of the

313 signals at a p-value level less than $0.05 / 14(\approx 0.0036)$ in the replication meta-analysis. In the

314 combined meta-analysis of discovery and replication GWAS, we detected four additional SNPS

315 independently associated with conversion to treatment (Figure 2b). Q-Q plots for the discovery 
medRxiv preprint doi: https://doi.org/10.1101/2021.08.30.21262305; this version posted August 31, 2021. The copyright holder for this preprint (which was not certified by peer review) is the author/funder, who has granted medRxiv a license to display the preprint in perpetuity.

All rights reserved. No reuse allowed without permission.

GWAS and the combined meta-analysis did not suggest inflation of test statistics due to systematic bias such as population substructure (genomic inflation factor $=1$ and 1.02 , respectively; Figure S1).

Of the 18 SNPs, four were common (MAF > 0.01) and the remainder were low frequency (MAF $=0.01)$ (Table 1). Three were located within $1 \mathrm{Mb}$ of previous PC GWAS-identified variants,

322 although they were not in linkage disequilibrium with these variants $\left(r^{2}<0.3\right)$. These were: intronic SNP rs4721243 of MAD1L1 (MIM: 602686) on chromosome 7 (CIDR European GWAS

\section{Transcriptome-Wide Association Study of Conversion from AS to Treatment}

329 In the multi-tissue TWAS analysis using S-MultiXcan, the imputed expression levels of two 330 genes were associated with conversion after Bonferroni correction for multiple testing: MAST3 (MIM: 612258; P-value=6.9 × 10 ${ }^{-7}$ ) and GAB2 (MIM: 606203; P-value=2.0 $\left.\times 10^{-6}\right)$. Imputed expression levels of two other genes suggested association with conversion: ARRDC2 (Pvalue $\left.=2.7 \times 10^{-5}\right)$ and CELSR1 (MIM: 604523; P-value $\left.=9.5 \times 10^{-5}\right)$. When looking only at

334 prostate tissue, we observed modest associations for MAST3 (P-value=0.08) and GAB2 (P-

335 value $=4.1 \times 10^{-4}$ ), as well as a suggestive association between imputed expression of the gene 336 ZNF644 (MIM: 614159) and conversion $\left(P\right.$-value $\left.=9.9 \times 10^{-5}\right)$.

338 Genetic Risk Scores and Conversion from AS to Treatment

339 Increasing GRS for PC susceptibility (GRS $)$ was positively associated with conversion from 340 AS to treatment, even after adjusting for clinical covariates (Figure 3a; Table S2). The fully 
medRxiv preprint doi: https://doi.org/10.1101/2021.08.30.21262305; this version posted August 31, 2021. The copyright holder for this preprint (which was not certified by peer review) is the author/funder, who has granted medRxiv a license to display the preprint in perpetuity.

All rights reserved. No reuse allowed without permission.

341 adjusted HR for conversion for men in the top decile of the GRSPC compared to the middle two

342 deciles was $1.13\left(95 \% \mathrm{Cl}, 0.94-1.36\right.$; Figure 3a; Table S2). Men in the bottom $10^{\text {th }}$ percentile of

343 the GRSPC distribution had a significantly lower conversion rate than the middle two deciles of

344 the $\mathrm{GRS}_{\mathrm{PC}}(\mathrm{HR}=0.69 ; 95 \% \mathrm{Cl}, 0.56-0.86$; Figure 3a; Table S2).

346 From the 36-variant GRS for PSA concentration (GRSPSA), we observed the opposite pattern:

347 increasing GRSPSA was inversely associated with conversion (Figure 3b; Table S3). Compared

348 to the $40-60^{\text {th }}$ percentiles, men in the bottom $10^{\text {th }}$ percentile of the PSA GRS distribution

349 experienced a shorter time to conversion (fully adjusted $\mathrm{HR}=1.25 ; 95 \% \mathrm{Cl}, 1.04-1.50$; Figure

350 3b; Table S3).

351

352

Potential Clinical Utility of the GRS

353 The time to conversion in the low- and intermediate-risk groups varied depending on whether

354 men were in the top or bottom deciles of the GRS

355 GRS $S_{P C}$, the Kaplan-Meier curves contrasting the top versus bottom deciles were significantly

356 different for the low- and intermediate-risk groups ( $p=3 \times 10^{-5}$ and $p=0.016$, respectively).

357 Similarly, the top and bottom deciles of the GRSPSA differed for the intermediate-risk groups

$358(p=0.003)$. There was no clear difference between the deciles of $G R S_{P C}$ or $G R S_{P S A}$ in patients 359 with high-risk disease.

360

361 A baseline model including age at diagnosis and principal components achieved an AUC $=0.55$

362 for time to conversion. This was substantially improved by incorporating the clinical

363 characteristics into the model: $A U C=0.653$ (Table S4). Adding the $\mathrm{GRS}_{\mathrm{PC}}$ to this model

364 resulted in modest improvement $(A U C=0.659)$. Augmenting this model with $G_{R S}$ PSA produced

365 minimal improvement $(\mathrm{AUC}=0.661)$. 
medRxiv preprint doi: https://doi.org/10.1101/2021.08.30.21262305; this version posted August 31, 2021. The copyright holder for this preprint (which was not certified by peer review) is the author/funder, who has granted medRxiv a license to display the preprint in perpetuity.

All rights reserved. No reuse allowed without permission.

\section{Discussion}

368 In this GWAS of PC patients managed with AS, we detected 18 novel SNPs and two candidate

369 genes associated with conversion. We further found that GRS for PC susceptibility in addition to

370 PSA level were associated with conversion, providing information beyond conventional clinical

371 and pathologic measures of the disease. These findings provide preliminary support for using

372 germline genetic information to inform the initial management of men with newly diagnosed,

373 clinically localized PC.

375 Of the 18 SNPs associated with conversion, 15 were not previously associated with PC risk.

376 These include a low-frequency (MAF $=0.01$ ) intronic variant, rs4721243 at MAD1L1, at a

377 previously identified PC locus ${ }^{43}$. The SNP was uncorrelated with the previously reported

378 genome-wide significant PC SNP at the locus (rs4513875, $r^{2}=0.012$ in the 1000 Genomes

379 global reference data). One detected SNP (rs74874116) was 32kb away from a PC-associated

380 indel (rs139135938), with little correlation $\left(r^{2}=0.015\right.$ in 1000 Genomes). The neighboring

381 gene, GATA5, encodes a transcription factor that contains two GATA-type zinc fingers and is

382 required during cardiovascular development ${ }^{62}$. This gene contains two variants previously

383 associated with benign prostatic hyperplasia (MIM: 600082) and associated lower urinary tract

384 symptoms $^{63}$ (MIM: 618612). Another SNP in a PC risk locus was rs1404610, nearby GL/2, a

385 transcription factor that one study found regulates the growth and tumorigenicity of prostate

386 cells $^{64}$.

388 Many of the novel SNPs we found to be associated with conversion are intronic, including SNPs

389 in genes involved in cellular signaling, growth, and differentiation. PRDM16 (MIM: 605557),

390 where rs6658664 is located, is associated with evasion of apoptosis by prostatic cancer cells ${ }^{65}$.

391 Intronic SNP rs115861550 in VAV2 (MIM: 600428) is upregulated in human PC tumors and is a

392 prognostic indicator for poor outcome ${ }^{66}$. Another intronic SNP, EBF3 (MIM: 607407), has been 
medRxiv preprint doi: https://doi.org/10.1101/2021.08.30.21262305; this version posted August 31, 2021. The copyright holder for this preprint (which was not certified by peer review) is the author/funder, who has granted medRxiv a license to display the preprint in perpetuity.

All rights reserved. No reuse allowed without permission.

393

shown to regulate the expression of genes involved in cell growth, proliferation, and apoptosis ${ }^{67}$. RECQL5 (MIM: 603781), where SNP rs820198 is located, regulates DNA repair intermediate structures, and studies have observed elevated RECQL5 expression in other cancers such as breast (MIM: 114480) and bladder (MIM: 109800) ${ }^{68-70}$. SNP rs820198 is annotated to an active CTCF (CCCTC-binding factor) binding site, and CTCF expression in linked to poor outcome in prostate cancer $^{71}$. Although intergenic, SNP rs77112978 is near NEDD4L (MIM: 606384), whose expression is decreased in PC ${ }^{72}$. Intergenic SNP rs55850837-A, associated with conversion in our study, was associated with reduced body mass index ${ }^{73}$ and body fat percentage ${ }^{74}$ in the phenome-wide association data curated by the IEU OpenGWAS Project ${ }^{75}$. SNP rs12452625, a UTR'3 variant of RFNG (MIM: 602578) gene, is correlated with variants associated with multiple traits, including heel bone mineral density, lung function, and waist-hip ratio $^{76,77}$. This SNP is also predicted to be a functional target of microRNA hsa-miR-629-3p, which may serve as a biomarker for lung metastases of triple-negative breast cancer ${ }^{78}$.

Our TWAS suggests a possible role for MAST3 and GAB2 in conversion. A study described MAST3 as an inflammatory bowel disease (IBD) susceptibility gene that regulates NF-kB activity through TLR4 ${ }^{79}$. Two recent studies have described increased risk for PC in men with IBD (MIM: 601458) ${ }^{80,81}$. Regarding GAB2, the knockdown of this gene in PC cells altered the expression of over 1,200 genes and inhibited p53 signaling ${ }^{82}$.

We found that the PC GRS based on 269 known risk variants was positively associated with conversion. Moreover, a PSA GRS based on 36 known genetic variants for PSA levels exhibited a weak inverse association with conversion. We expected these GRS to have opposite directions of effect on conversion, given that the PSA GRS may reflect the potential ascertainment of higher-risk PC in men with lower genetically predicted PSA levels. While the 
medRxiv preprint doi: https://doi.org/10.1101/2021.08.30.21262305; this version posted August 31, 2021. The copyright holder for this preprint (which was not certified by peer review) is the author/funder, who has granted medRxiv a license to display the preprint in perpetuity.

All rights reserved. No reuse allowed without permission.

overall GRS only contributed modest model discrimination beyond established risk factors for

419 conversion, the associations observed in the tails (i.e., deciles) of the GRS distribution were

420 most pronounced among men in low and intermediate clinicopathological categories. This

421 finding suggests that men with lower-risk disease, but high PC GRS (or low PSA GRS) may be

422 more likely candidates for early treatment or possibly a higher intensity of surveillance. A recent

423 study of European ancestry men with low-risk PC managed on AS reported associations

424 between higher PC GRS with more positive cores and with bilateral tumor location at diagnostic

425 and surveillance biopsy ${ }^{83}$; note that $\sim 50 \%$ of the men in this previous study are also included

426 here, comprising $\sim 10 \%$ of our study population.

427

428 Strengths of this study include leveraging a large, multi-institutional collaborative study of AS to

429 model the effects of genetic risk variants independent of clinical risk parameters. Sixty-three

430 percent of the replication sample $(n=714)$ were men of non-European genetic ancestry,

431 allowing us to test the generalizability of the SNPs discovered in the European sample. Our

432 GRS included the most recently available GWAS weights from PC and PSA. Limitations of our

433 study included the lack of confirmatory or surveillance biopsies to reduce misclassification of

434 clinical parameters at diagnosis and follow-up. In addition, conversion could conflate disease

435 progression with patient anxiety and/or physician preference for AS management. However,

436 discontinuing AS due to anxiety was relatively uncommon in this study (about $6 \%$ of events),

437 and these cases were censored in the GWAS analysis. Furthermore, given the relatively short

438 follow-up for more robust PC outcomes, the sample sizes for PSA failure after treatment

$439(n=124)$, metastases $(n=29)$, or PC-specific death $(n=11)$ are too small for a GWAS analysis.

441 In summary, we have undertaken the first GWAS of conversion among men diagnosed

442 with PC. This multi-institutional study detected a genetic basis of conversion, suggesting 
medRxiv preprint doi: https://doi.org/10.1101/2021.08.30.21262305; this version posted August 31, 2021. The copyright holder for this preprint (which was not certified by peer review) is the author/funder, who has granted medRxiv a license to display the preprint in perpetuity.

All rights reserved. No reuse allowed without permission.

443 that genetic factors may provide valuable information to stratify men with PC by their

444 risk of discontinuing AS. Important future work will expand this study to more men

445 placed on AS, increasing our ability to detect genetic variants associated with

446 conversion. This may in turn help address concerns that biopsy sampling may

447 underestimate a tumor's aggressiveness and provide a more personalized approach to

448 decisions surrounding AS. 
medRxiv preprint doi: https://doi.org/10.1101/2021.08.30.21262305; this version posted August 31, 2021. The copyright holder for this preprint (which was not certified by peer review) is the author/funder, who has granted medRxiv a license to display the preprint in perpetuity.

All rights reserved. No reuse allowed without permission.

\section{Supplemental Data}

450 Supplemental data include one figure and four tables.

451

452 Disclosures of Interests

453 The authors declare no competing interests.

\section{Declarations}

456 This study was approved by the Robert H. Lurie Comprehensive Cancer Center of Northwestern

457 University Scientific Review (IRB) Committees. The approval number is STU00077147, which

458 was most recently given annual approval on $7 / 8 / 2021$.

\section{Acknowledgements}

461 Funding/Support: P50CA180995 (William J. Catalona) 08/01/15 - 07/31/20 NIH/NCI SPORE

462 in Prostate Cancer PI on the SPORE grant, Center for Inherited Disease Research (CIDR)

463 award from the NCl for patient sample genotyping (X01HG009642), Urological Research

464 Foundation (William J. Catalona), NorthShore University Health System, Evanston, IL, USA

465 (Brian T. Helfand). Additional support was provided by award numbers R01CA158627 and

466 R01CA195505 (Leonard S. Marks), P50 CA186786 (Todd M. Morgan), UL1 TR000445 from

467 NCATS/NIH for Vanderbilt REDCap (Daniel A. Barocas), P50 CA097186 and K05 CA175147

468 (Janet L. Stanford), and U01 CA113913 (Martin G. Sanda) from the National Institute of Health, 469 and W81XWH-13-2-0074 (Peter R. Carroll) from the Department of Defense.

\section{Web Resources}

472 METAL (https://genome.sph.umich.edu/wiki/METAL Documentation)

473 PLINK v1.9 (https://www.cog-genomics.org/plink/)

474 MetaXcan, S-MetaXcan (https://github.com/hakyimlab/MetaXcan) 
medRxiv preprint doi: https://doi.org/10.1101/2021.08.30.21262305; this version posted August 31, 2021. The copyright holder for this preprint (which was not certified by peer review) is the author/funder, who has granted medRxiv a license to display the preprint in perpetuity.

All rights reserved. No reuse allowed without permission.

475 IEU OpenGWAS Project (https://gwas.mrcieu.ac.uk/)

476 Online Mendelian Inheritance in Man (http://www.omim.org)

477

\section{Data Availability}

479 The MEGA data analyzed in this publication have been deposited in dbGap and are accessible 480 through dbGap Study Accession number phs002056.v1.p1. 
medRxiv preprint doi: https://doi.org/10.1101/2021.08.30.21262305; this version posted August 31, 2021. The copyright holder for this preprint (which was not certified by peer review) is the author/funder, who has granted medRxiv a license to display the preprint in perpetuity.

All rights reserved. No reuse allowed without permission.

481

482

483

484

485

486

487

488

489

490

491

492

493

494

495

496

497

498 499 Knipper, A.-S., Pompe, R., Zorn, K.C., et al. (2020). Prostate Cancer Grade and Stage 500 Misclassification in Active Surveillance Candidates: Black Versus White Patients. Journal of the 501 National Comprehensive Cancer Network 18, 1492-1499.

\section{References}

1. Washington, S.L., Jeong, C.W., Lonergan, P.E., Herlemann, A., Gomez, S.L., Carroll, P.R., and Cooperberg, M.R. (2020). Regional Variation in Active Surveillance for Low-Risk Prostate Cancer in the US. JAMA Netw Open 3, e2031349.

2. Mohler, J.L., Antonarakis, E.S., Armstrong, A.J., D’Amico, A.V., Davis, B.J., Dorff, T., Eastham, J.A., Enke, C.A., Farrington, T.A., Higano, C.S., et al. (2019). Prostate Cancer, Version 2.2019, NCCN Clinical Practice Guidelines in Oncology. J Natl Compr Canc Netw 17, 479-505.

3. Loeb, S., Byrne, N., Makarov, D.V., Lepor, H., and Walter, D. (2018). Use of Conservative Management for Low-Risk Prostate Cancer in the Veterans Affairs Integrated Health Care System From 2005-2015. JAMA 319, 2231-2233.

4. Parikh, R.B., Robinson, K.W., Chhatre, S., Medvedeva, E., Cashy, J.P., Veera, S., Bauml, J.M., Fojo, T., Navathe, A.S., Malkowicz, S.B., et al. (2020). Comparison by Race of Conservative Management for Low-Risk and Intermediate-Risk Prostate Cancers in Veterans From 2004 to 2018. JAMA Netw Open 3, e2018318.

5. Loeb, S., Folkvaljon, Y., Curnyn, C., Robinson, D., Bratt, O., and Stattin, P. (2017). Uptake of Active Surveillance for Very-Low-Risk Prostate Cancer in Sweden. JAMA Oncol 3, 1393-1398.

98 6. Stolzenbach, L.F., Rosiello, G., Pecoraro, A., Palumbo, C., Luzzago, S., Deuker, M., Tian, Z., 
7. Klotz, L., Vesprini, D., Sethukavalan, P., Jethava, V., Zhang, L., Jain, S., Yamamoto, T., Mamedov, A., and Loblaw, A. (2015). Long-term follow-up of a large active surveillance cohort

504 of patients with prostate cancer. J Clin Oncol 33, 272-277.

8. Cooperberg, M.R., Brooks, J.D., Faino, A.V., Newcomb, L.F., Kearns, J.T., Carroll, P.R.,

Dash, A., Etzioni, R., Fabrizio, M.D., Gleave, M.E., et al. (2018). Refined Analysis of Prostate-

507 specific Antigen Kinetics to Predict Prostate Cancer Active Surveillance Outcomes. Eur Urol 74, $508 \quad 211-217$.

9. Williams, C., Khondakar, N.R., Daneshvar, M.A., O'Connor, L.P., Gomella, P.T., Mehralivand,

510 S., Yerram, N.K., Egan, J., Gurram, S., Rompré-Brodeur, A., et al. (2021). The Risk of Prostate

511 Cancer Progression in Active Surveillance Patients With Bilateral Disease Detected by

512 Combined MRI-Fusion and Systematic Biopsy. J Urol 101097JU0000000000001941.

513 10. Eggener, S.E., Rumble, R.B., Armstrong, A.J., Morgan, T.M., Crispino, T., Cornford, P., van

514 der Kwast, T., Grignon, D.J., Rai, A.J., Agarwal, N., et al. (2020). Molecular Biomarkers in

515 Localized Prostate Cancer: ASCO Guideline. J Clin Oncol 38, 1474-1494.

516 11. Black, M.H., Li, S., LaDuca, H., Lo, M., Chen, J., Hoiness, R., Gutierrez, S., Tippin-Davis,

517 B., Lu, H., Gielzak, M., et al. (2020). Validation of a prostate cancer polygenic risk score.

518 Prostate 80, 1314-1321.

519 12. Langeberg, W.J., Isaacs, W.B., and Stanford, J.L. (2007). Genetic etiology of hereditary 520 prostate cancer. Front Biosci 12, 4101-4110.

521 13. Lichtenstein, P., Holm, N.V., Verkasalo, P.K., Iliadou, A., Kaprio, J., Koskenvuo, M.,

522 Pukkala, E., Skytthe, A., and Hemminki, K. (2000). Environmental and heritable factors in the

523 causation of cancer--analyses of cohorts of twins from Sweden, Denmark, and Finland. N Engl J

524 Med 343, 78-85. 
medRxiv preprint doi: https://doi.org/10.1101/2021.08.30.21262305; this version posted August 31, 2021. The copyright holder for this preprint (which was not certified by peer review) is the author/funder, who has granted medRxiv a license to display the preprint in perpetuity.

All rights reserved. No reuse allowed without permission.

525

526

527

528

529

530

531

532

533

534

535

536

537

538

539

540

541

542

543

544

545

546

547

14. Narod, S. (1999). Genetic epidemiology of prostate cancer. Biochim Biophys Acta 1423, F113.

15. Schumacher, F.R., Al Olama, A.A., Berndt, S.I., Benlloch, S., Ahmed, M., Saunders, E.J., Dadaev, T., Leongamornlert, D., Anokian, E., Cieza-Borrella, C., et al. (2018). Association analyses of more than 140,000 men identify 63 new prostate cancer susceptibility loci. Nat Genet 50, 928-936.

16. Ahn, J., Kibel, A.S., Park, J.Y., Rebbeck, T.R., Rennert, H., Stanford, J.L., Ostrander, E.A., Chanock, S., Wang, M.-H., Mittal, R.D., et al. (2011). Prostate cancer predisposition loci and risk of metastatic disease and prostate cancer recurrence. Clin Cancer Res 17, 1075-1081.

17. Amin Al Olama, A., Kote-Jarai, Z., Schumacher, F.R., Wiklund, F., Berndt, S.I., Benlloch, S., Giles, G.G., Severi, G., Neal, D.E., Hamdy, F.C., et al. (2013). A meta-analysis of genome-wide association studies to identify prostate cancer susceptibility loci associated with aggressive and non-aggressive disease. Hum Mol Genet 22, 408-415.

18. Bao, B.-Y., Pao, J.-B., Huang, C.-N., Pu, Y.-S., Chang, T.-Y., Lan, Y.-H., Lu, T.-L., Lee, H.Z., Chen, L.-M., Ting, W.-C., et al. (2012). Significant associations of prostate cancer susceptibility variants with survival in patients treated with androgen-deprivation therapy. Int $J$ Cancer 130, 876-884.

19. Bensen, J.T., Xu, Z., Smith, G.J., Mohler, J.L., Fontham, E.T.H., and Taylor, J.A. (2013). Genetic polymorphism and prostate cancer aggressiveness: a case-only study of 1,536 GWAS and candidate SNPs in African-Americans and European-Americans. Prostate 73, 11-22.

20. Chen, M., Huang, Y.-C., Yang, S., Hsu, J.-M., Chang, Y.-H., Huang, W.J.-S., and Chen, Y.M.A. (2010). Common variants at 8q24 are associated with prostate cancer risk in Taiwanese men. Prostate 70, 502-507. 
21. Eeles, R.A., Kote-Jarai, Z., Giles, G.G., Olama, A.A.A., Guy, M., Jugurnauth, S.K.,

Mulholland, S., Leongamornlert, D.A., Edwards, S.M., Morrison, J., et al. (2008). Multiple newly identified loci associated with prostate cancer susceptibility. Nat Genet 40, 316-321.

551 22. Eeles, R.A., Olama, A.A.A., Benlloch, S., Saunders, E.J., Leongamornlert, D.A.,

552 Tymrakiewicz, M., Ghoussaini, M., Luccarini, C., Dennis, J., Jugurnauth-Little, S., et al. (2013).

553 Identification of 23 new prostate cancer susceptibility loci using the iCOGS custom genotyping

554 array. Nat Genet 45, 385-391, 391e1-2.

23. FitzGerald, L.M., Kwon, E.M., Conomos, M.P., Kolb, S., Holt, S.K., Levine, D., Feng, Z.,

556 Ostrander, E.A., and Stanford, J.L. (2011). Genome-wide association study identifies a genetic

557 variant associated with risk for more aggressive prostate cancer. Cancer Epidemiol Biomarkers

558 Prev 20, 1196-1203.

559 24. Gudmundsson, J., Sulem, P., Rafnar, T., Bergthorsson, J.T., Manolescu, A., Gudbjartsson,

560 D., Agnarsson, B.A., Sigurdsson, A., Benediktsdottir, K.R., Blondal, T., et al. (2008). Common

561 sequence variants on 2 p15 and Xp11.22 confer susceptibility to prostate cancer. Nat Genet 40, $562 \quad 281-283$.

563 25. Gudmundsson, J., Besenbacher, S., Sulem, P., Gudbjartsson, D.F., Olafsson, I.,

564 Arinbjarnarson, S., Agnarsson, B.A., Benediktsdottir, K.R., Isaksson, H.J., Kostic, J.P., et al.

565 (2010). Genetic correction of PSA values using sequence variants associated with PSA levels.

566 Sci Transl Med 2, 62ra92.

567 26. Helfand, B.T., Loeb, S., Cashy, J., Meeks, J.J., Thaxton, C.S., Han, M., and Catalona, W.J. 568 (2008). Tumor characteristics of carriers and noncarriers of the deCODE 8q24 prostate cancer 569 susceptibility alleles. J Urol 179, 2197-2201; discussion 2202. 
medRxiv preprint doi: https://doi.org/10.1101/2021.08.30.21262305; this version posted August 31, 2021. The copyright holder for this preprint (which was not certified by peer review) is the author/funder, who has granted medRxiv a license to display the preprint in perpetuity.

All rights reserved. No reuse allowed without permission.

570

571

572

573

574

575

576

577

578

579

580

581

582

583

584

585

586

587

588

589

590

591

592

27. Helfand, B.T., Kan, D., Modi, P., and Catalona, W.J. (2011). Prostate cancer risk alleles significantly improve disease detection and are associated with aggressive features in patients with a "normal" prostate specific antigen and digital rectal examination. Prostate 71, 394-402.

28. Lange, E.M., Johnson, A.M., Wang, Y., Zuhlke, K.A., Lu, Y., Ribado, J.V., Keele, G.R., Li, J., Duan, Q., Li, G., et al. (2014). Genome-wide association scan for variants associated with earlyonset prostate cancer. PLoS One 9, e93436.

29. Lange, E.M., Salinas, C.A., Zuhlke, K.A., Ray, A.M., Wang, Y., Lu, Y., Ho, L.A., Luo, J., and Cooney, K.A. (2012). Early onset prostate cancer has a significant genetic component. Prostate $72,147-156$.

30. Lin, D.W., FitzGerald, L.M., Fu, R., Kwon, E.M., Zheng, S.L., Kolb, S., Wiklund, F., Stattin, P., Isaacs, W.B., Xu, J., et al. (2011). Genetic variants in the LEPR, CRY1, RNASEL, IL4, and ARVCF genes are prognostic markers of prostate cancer-specific mortality. Cancer Epidemiol Biomarkers Prev 20, 1928-1936.

31. Loeb, S., Carter, H.B., Walsh, P.C., Isaacs, W.B., Kettermann, A., Tanaka, T., Ferrucci, L., and Metter, E.J. (2009). Single nucleotide polymorphisms and the likelihood of prostate cancer at a given prostate specific antigen level. J Urol 182, 101-104; discussion 105.

32. Pal, P., Xi, H., Guha, S., Sun, G., Helfand, B.T., Meeks, J.J., Suarez, B.K., Catalona, W.J., and Deka, R. (2009). Common variants in 8q24 are associated with risk for prostate cancer and tumor aggressiveness in men of European ancestry. Prostate 69, 1548-1556.

33. Pomerantz, M.M., Werner, L., Xie, W., Regan, M.M., Lee, G.-S.M., Sun, T., Evan, C., Petrozziello, G., Nakabayashi, M., Oh, W.K., et al. (2011). Association of prostate cancer risk Loci with disease aggressiveness and prostate cancer-specific mortality. Cancer Prev Res (Phila) 4, 719-728. 
medRxiv preprint doi: https://doi.org/10.1101/2021.08.30.21262305; this version posted August 31, 2021. The copyright holder for this preprint (which was not certified by peer review) is the author/funder, who has granted medRxiv a license to display the preprint in perpetuity.

All rights reserved. No reuse allowed without permission.

593 34. Sun, J., Lange, E.M., Isaacs, S.D., Liu, W., Wiley, K.E., Lange, L., Gronberg, H., Duggan,

594 D., Carpten, J.D., Walsh, P.C., et al. (2008). Chromosome 8q24 risk variants in hereditary and

595 non-hereditary prostate cancer patients. Prostate 68, 489-497.

596 35. Xu, J., Zheng, S.L., Isaacs, S.D., Wiley, K.E., Wiklund, F., Sun, J., Kader, A.K., Li, G.,

597 Purcell, L.D., Kim, S.-T., et al. (2010). Inherited genetic variant predisposes to aggressive but

598 not indolent prostate cancer. Proc Natl Acad Sci U S A 107, 2136-2140.

599 36. Goh, C.L., and Eeles, R.A. (2014). Germline genetic variants associated with prostate

600 cancer and potential relevance to clinical practice. Recent Results Cancer Res 202, 9-26.

601 37. Ishak, M.B., and Giri, V.N. (2011). A systematic review of replication studies of prostate

602 cancer susceptibility genetic variants in high-risk men originally identified from genome-wide

603 association studies. Cancer Epidemiol Biomarkers Prev 20, 1599-1610.

604 38. Kim, S.-T., Cheng, Y., Hsu, F.-C., Jin, T., Kader, A.K., Zheng, S.L., Isaacs, W.B., Xu, J., and

605 Sun, J. (2010). Prostate cancer risk-associated variants reported from genome-wide association

606 studies: meta-analysis and their contribution to genetic Variation. Prostate 70, 1729-1738.

607 39. Lindström, S., Zheng, S.L., Wiklund, F., Jonsson, B.-A., Adami, H.-O., Bälter, K.A., Brookes,

608 A.J., Sun, J., Chang, B.-L., Liu, W., et al. (2006). Systematic replication study of reported

609 genetic associations in prostate cancer: Strong support for genetic variation in the androgen

610 pathway. Prostate 66, 1729-1743.

611 40. Pomerantz, M.M., and Freedman, M.L. (2010). Genetics of prostate cancer risk. Mt Sinai J 612 Med 77, 643-654. 
medRxiv preprint doi: https://doi.org/10.1101/2021.08.30.21262305; this version posted August 31, 2021. The copyright holder for this preprint (which was not certified by peer review) is the author/funder, who has granted medRxiv a license to display the preprint in perpetuity.

All rights reserved. No reuse allowed without permission.

613 41. Na, R., Liu, F., Zhang, P., Ye, D., Xu, C., Shao, Q., Qi, J., Wang, X., Chen, Z., Wang, M., et

614 al. (2013). Evaluation of reported prostate cancer risk-associated SNPs from genome-wide

615 association studies of various racial populations in Chinese men. Prostate 73, 1623-1635.

616 42. Bensen, J.T., Xu, Z., McKeigue, P.M., Smith, G.J., Fontham, E.T.H., Mohler, J.L., and

617 Taylor, J.A. (2014). Admixture mapping of prostate cancer in African Americans participating in

618 the North Carolina-Louisiana Prostate Cancer Project (PCaP). Prostate 74, 1-9.

619 43. Conti, D.V., Darst, B.F., Moss, L.C., Saunders, E.J., Sheng, X., Chou, A., Schumacher,

620 F.R., Olama, A.A.A., Benlloch, S., Dadaev, T., et al. (2021). Trans-ancestry genome-wide

621 association meta-analysis of prostate cancer identifies new susceptibility loci and informs

622 genetic risk prediction. Nat Genet 53, 65-75.

623 44. Chen, H., Liu, X., Brendler, C.B., Ankerst, D.P., Leach, R.J., Goodman, P.J., Lucia, M.S.,

624 Tangen, C.M., Wang, L., Hsu, F.-C., et al. (2016). Adding genetic risk score to family history

625 identifies twice as many high-risk men for prostate cancer: Results from the prostate cancer

626 prevention trial. Prostate 76, 1120-1129.

627 45. Helfand, B.T., Kearns, J., Conran, C., and Xu, J. (2016). Clinical validity and utility of genetic

628 risk scores in prostate cancer. Asian J Androl 18, 509-514.

629 46. Huynh-Le, M.-P., Karunamuni, R., Fan, C.C., Thompson, W.K., Muir, K., Lophatananon, A.,

630 Tye, K., Wolk, A., Håkansson, N., Mills, I.G., et al. (2021). Common genetic and clinical risk

631 factors: association with fatal prostate cancer in the Cohort of Swedish Men. Prostate Cancer

632 Prostatic Dis.

633 47. Helfand, B.T., and Xu, J. (2021). Germline Testing for Prostate Cancer Prognosis:

634 Implications for Active Surveillance. Urol Clin North Am 48, 401-409. 
medRxiv preprint doi: https://doi.org/10.1101/2021.08.30.21262305; this version posted August 31, 2021. The copyright holder for this preprint (which was not certified by peer review) is the author/funder, who has granted medRxiv a license to display the preprint in perpetuity.

All rights reserved. No reuse allowed without permission.

635

636

637

638

639

640

641

642

643

644

645

646

647

648

649

650

651

652

653

654

655

656

48. Hoffmann, T.J., Passarelli, M.N., Graff, R.E., Emami, N.C., Sakoda, L.C., Jorgenson, E., Habel, L.A., Shan, J., Ranatunga, D.K., Quesenberry, C.P., et al. (2017). Genome-wide association study of prostate-specific antigen levels identifies novel loci independent of prostate cancer. Nat Commun 8, 14248.

49. Cooley, L.F., Emeka, A.A., Meyers, T.J., Helfand, B.T., Scholtens, D.M., Witte, J.S., and Catalona, W.J. Factors Associated with Time to Conversion from Active Surveillance to Treatment for Prostate Cancer in a Multi-institutional Cohort. Journal of Urology Manuscript accepted for publication,

50. Van Hemelrijck, M., Ji, X., Helleman, J., Roobol, M.J., van der Linden, W., Nieboer, D., Bangma, C.H., Frydenberg, M., Rannikko, A., Lee, L.S., et al. (2019). Reasons for Discontinuing Active Surveillance: Assessment of 21 Centres in 12 Countries in the Movember GAP3 Consortium. Eur Urol 75, 523-531.

51. Gregg, J.R., Davis, J.W., Reichard, C., Wang, X., Achim, M., Chapin, B.F., Pisters, L., Pettaway, C., Ward, J.F., Choi, S., et al. (2020). Determining Clinically Based Factors Associated With Reclassification in the Pre-MRI Era using a Large Prospective Active Surveillance Cohort. Urology 138, 91-97.

52. Welty, C.J., Cowan, J.E., Nguyen, H., Shinohara, K., Perez, N., Greene, K.L., Chan, J.M., Meng, M.V., Simko, J.P., Cooperberg, M.R., et al. (2015). Extended followup and risk factors for disease reclassification in a large active surveillance cohort for localized prostate cancer. J Urol 193, 807-811.

53. Hamdy, F.C., Donovan, J.L., Lane, J.A., Mason, M., Metcalfe, C., Holding, P., Davis, M., Peters, T.J., Turner, E.L., Martin, R.M., et al. (2016). 10-Year Outcomes after Monitoring, 
medRxiv preprint doi: https://doi.org/10.1101/2021.08.30.21262305; this version posted August 31, 2021. The copyright holder for this preprint (which was not certified by peer review) is the author/funder, who has granted medRxiv a license to display the preprint in perpetuity.

All rights reserved. No reuse allowed without permission.

Surgery, or Radiotherapy for Localized Prostate Cancer. New England Journal of Medicine 375,

658 $1415-1424$.

659

54. Harris, P.A., Taylor, R., Thielke, R., Payne, J., Gonzalez, N., and Conde, J.G. (2009).

660

Research electronic data capture (REDCap)--a metadata-driven methodology and workflow

661 process for providing translational research informatics support. J Biomed Inform 42, 377-381.

662 55. Harris, P.A., Taylor, R., Minor, B.L., Elliott, V., Fernandez, M., O’Neal, L., McLeod, L.,

663 Delacqua, G., Delacqua, F., Kirby, J., et al. (2019). The REDCap consortium: Building an

664 international community of software platform partners. J Biomed Inform 95, 103208.

665 56. Gordetsky, J., and Epstein, J. (2016). Grading of prostatic adenocarcinoma: current state 666 and prognostic implications. Diagn Pathol 11, 25.

667 57. Alexander, D.H., Novembre, J., and Lange, K. (2009). Fast model-based estimation of 668 ancestry in unrelated individuals. Genome Res 19, 1655-1664.

669 58. Rizvi, A.A., Karaesmen, E., Morgan, M., Preus, L., Wang, J., Sovic, M., Hahn, T., and

670 Sucheston-Campbell, L.E. (2019). gwasurvivr: an R package for genome-wide survival analysis.

671 Bioinformatics 35, 1968-1970.

672 59. Willer, C.J., Li, Y., and Abecasis, G.R. (2010). METAL: fast and efficient meta-analysis of 673 genomewide association scans. Bioinformatics 26, 2190-2191.

674 60. Barbeira, A.N., Pividori, M., Zheng, J., Wheeler, H.E., Nicolae, D.L., and Im, H.K. (2019).

675 Integrating predicted transcriptome from multiple tissues improves association detection. PLOS

676 Genetics 15, e1007889.

677 61. Chambless, L.E., and Diao, G. (2006). Estimation of time-dependent area under the ROC 678 curve for long-term risk prediction. Stat Med 25, 3474-3486. 
medRxiv preprint doi: https://doi.org/10.1101/2021.08.30.21262305; this version posted August 31, 2021. The copyright holder for this preprint (which was not certified by peer review) is the author/funder, who has granted medRxiv a license to display the preprint in perpetuity.

All rights reserved. No reuse allowed without permission.

679 62. Reiter, J.F., Alexander, J., Rodaway, A., Yelon, D., Patient, R., Holder, N., and Stainier, 680 D.Y.R. (1999). Gata5 is required for the development of the heart and endoderm in zebrafish.

681 Genes Dev 13, 2983-2995.

63. Gudmundsson, J., Sigurdsson, J.K., Stefansdottir, L., Agnarsson, B.A., Isaksson, H.J.,

683 Stefansson, O.A., Gudjonsson, S.A., Gudbjartsson, D.F., Masson, G., Frigge, M.L., et al.

684 (2018). Genome-wide associations for benign prostatic hyperplasia reveal a genetic correlation 685 with serum levels of PSA. Nat Commun 9, 4568.

64. Thiyagarajan, S., Bhatia, N., Reagan-Shaw, S., Cozma, D., Thomas-Tikhonenko, A.,

687 Ahmad, N., and Spiegelman, V.S. (2007). Role of GLI2 transcription factor in growth and

688 tumorigenicity of prostate cells. Cancer Res 67, 10642-10646.

689 65. Zhu, S., Xu, Y., Song, M., Chen, G., Wang, H., Zhao, Y., Wang, Z., and Li, F. (2016).

690 PRDM16 is associated with evasion of apoptosis by prostatic cancer cells according to RNA 691 interference screening. Mol Med Rep 14, 3357-3361.

692 66. Magani, F., Peacock, S.O., Rice, M.A., Martinez, M.J., Greene, A.M., Magani, P.S., Lyles, 693 R., Weitz, J.R., and Burnstein, K.L. (2017). Targeting AR Variant-Coactivator Interactions to 694 Exploit Prostate Cancer Vulnerabilities. Mol Cancer Res 15, 1469-1480.

67. Zhao, L.Y., Niu, Y., Santiago, A., Liu, J., Albert, S.H., Robertson, K.D., and Liao, D. (2006).

An EBF3-mediated transcriptional program that induces cell cycle arrest and apoptosis. Cancer

Res 66, 9445-9452.

68. Arora, A., Abdel-Fatah, T.M.A., Agarwal, D., Doherty, R., Croteau, D.L., Moseley, P.M., 
69. Chen, E., Ahn, J.S., Sykes, D.B., Breyfogle, L.J., Godfrey, A.L., Nangalia, J., Ko, A.,

704 Induced Replication Stress and Genomic Instability. Cell Rep 13, 2345-2352.

705 70. Patterson, K., Arya, L., Bottomley, S., Morgan, S., Cox, A., Catto, J., and Bryant, H.E.

706 (2016). Altered RECQL5 expression in urothelial bladder carcinoma increases cellular

707 proliferation and makes RECQL5 helicase activity a novel target for chemotherapy. Oncotarget

$708 \quad 7,76140-76150$.

709 71. Höflmayer, D., Steinhoff, A., Hube-Magg, C., Kluth, M., Simon, R., Burandt, E., Tsourlakis,

710 M.C., Minner, S., Sauter, G., Büscheck, F., et al. (2020). Expression of CCCTC-binding factor

711 (CTCF) is linked to poor prognosis in prostate cancer. Molecular Oncology 14, 129-138.

712 72. Hu, X.Y., Xu, Y.M., Fu, Q., Yu, J.J., and Huang, J. (2009). Nedd4L expression is

713 downregulated in prostate cancer compared to benign prostatic hyperplasia. Eur J Surg Oncol

$71435,527-531$.

715 73. UK Biobank.

716 74. Elsworth, B.L. (2017). MRC IEU UK Biobank GWAS pipeline version 1.

717 75. Elsworth, B., Lyon, M., Alexander, T., Liu, Y., Matthews, P., Hallett, J., Bates, P., Palmer, T.,

718 Haberland, V., Smith, G.D., et al. (2020). The MRC IEU OpenGWAS data infrastructure

719 (Genetics).

720 76. Kichaev, G., Bhatia, G., Loh, P.-R., Gazal, S., Burch, K., Freund, M.K., Schoech, A.,

721 Pasaniuc, B., and Price, A.L. (2019). Leveraging Polygenic Functional Enrichment to Improve

722 GWAS Power. Am J Hum Genet 104, 65-75. 
medRxiv preprint doi: https://doi.org/10.1101/2021.08.30.21262305; this version posted August 31, 2021. The copyright holder for this preprint (which was not certified by peer review) is the author/funder, who has granted medRxiv a license to display the preprint in perpetuity.

All rights reserved. No reuse allowed without permission.

723 77. Lotta, L.A., Wittemans, L.B.L., Zuber, V., Stewart, I.D., Sharp, S.J., Luan, J., Day, F.R., Li,

724 C., Bowker, N., Cai, L., et al. (2018). Association of Genetic Variants Related to Gluteofemoral

725 vs Abdominal Fat Distribution With Type 2 Diabetes, Coronary Disease, and Cardiovascular

726 Risk Factors. JAMA 320, 2553-2563.

727 78. Wang, J., Song, C., Tang, H., Zhang, C., Tang, J., Li, X., Chen, B., and Xie, X. (2017). miR-

728 629-3p may serve as a novel biomarker and potential therapeutic target for lung metastases of

729 triple-negative breast cancer. Breast Cancer Res 19, 72.

730 79. Labbé, C., Goyette, P., Lefebvre, C., Stevens, C., Green, T., Tello-Ruiz, M.K., Cao, Z.,

731 Landry, A.L., Stempak, J., Annese, V., et al. (2008). MAST3: a novel IBD risk factor that

732 modulates TLR4 signaling. Genes Immun 9, 602-612.

733 80. Burns, J.A., Weiner, A.B., Catalona, W.J., Li, E.V., Schaeffer, E.M., Hanauer, S.B., Strong,

734 S., Burns, J., Hussain, M.H.A., and Kundu, S.D. (2019). Inflammatory Bowel Disease and the

735 Risk of Prostate Cancer. Eur Urol 75, 846-852.

736 81. Meyers, T.J., Weiner, A.B., Graff, R.E., Desai, A.S., Cooley, L.F., Catalona, W.J., Hanauer,

737 S.B., Wu, J.D., Schaeffer, E.M., Abdulkadir, S.A., et al. (2020). Association between

738 inflammatory bowel disease and prostate cancer: A large-scale, prospective, population-based

739 study. Int J Cancer 147, 2735-2742.

740 82. Qiao, X.-R., Zhang, X., Mu, L., Tian, J., and Du, Y. (2020). GRB2-associated binding protein

7412 regulates multiple pathways associated with the development of prostate cancer. Oncol Lett

$742 \quad 20,99$.

743 83. Xu, J., Isaacs, W.B., Mamawala, M., Shi, Z., Landis, P., Petkewicz, J., Wei, J., Wang, C.-H.,

744 Resurreccion, W.K., Na, R., et al. (2021). Association of prostate cancer polygenic risk score

745 with number and laterality of tumor cores in active surveillance patients. Prostate 81, 703-709. 
medRxiv preprint doi: https://doi.org/10.1101/2021.08.30.21262305; this version posted August 31, 2021. The copyright holder for this preprint (which was not certified by peer review) is the author/funder, who has granted medRxiv a license to display the preprint in perpetuity.

Figure Titles and Legends

748 Figure 1. Flow chart highlighting the approach and samples used in the genome-wide

749 association analysis. First, we undertook a discovery GWAS in men of European ancestry.

750 Fourteen SNPs were associated with conversion $\left(P<5 \times 10^{-8}\right)$. All SNPs were evaluated for

751 replication in the replication cohorts alone and then in a meta-analysis combining the discovery

752 and replication cohorts. Four additional SNPs reached statistical significance in the combined

753 meta-analysis $\left(P<5 \times 10^{-8}\right)$.

754

755

Figure 2. Results from the GWASs of conversion from AS to treatment (a) in 5,222

756

prostate cancer patients of European ancestry; (b) in discovery and replication cohorts. P values

are for variant associations with conversion, adjusted for age and ten ancestry principal

758

components using Cox proportional hazards models. Blue dashed line denotes the genome-

759

wide significance threshold. Orange peaks indicate genome-wide significant hits $\left(P<5 \times 10^{-8}\right)$.

760

The top variants in each chromosome are annotated with their rsID.

761

762

Figure 3. Association between time to conversion from AS to treatment (a) with the prostate cancer GRS; (b) with the prostate-specific antigen GRS . The fifth and sixth deciles of prostate cancer GRS are used as the reference. Bars indicate 95\% confidence intervals (Cl) around the hazard ratio (HR) estimates. The minimally adjusted model includes age and the first

76610 genetic prinicpal components. The fully adjusted model also includes Gleason grade group

767 (GG1, GG2, or $\geq$ GG3); PSA concentration (ng/mL); clinical stage (cT1, cT2, or cT3/cT4); and number of positive biopsy cores (1-2, 3, or $\geq 4)$. 
medRxiv preprint doi: https://doi.org/10.1101/2021.08.30.21262305; this version posted August 31, 2021. The copyright holder for this preprint (which was not certified by peer review) is the author/funder, who has granted medRxiv a license to display the preprint in perpetuity.

All rights reserved. No reuse allowed without permission.

772 and bottom deciles of genetic risk scores for prostate cancer (GRSPC, panel a) and for PSA

773 levels (GRSPSA, panel b). The curves within each risk category are compared between the top

774 and bottom GRS deciles using a log-rank test (P-values given next to corresponding curves). 
medRxiv preprint doi: https://doi.org/10.1101/2021.08.30.21262305; this version posted August 31, 2021. The copyright holder for this preprint (which was not certified by peer review) is the author/funder, who has granted medRxiv a license to display the preprint in perpetuity. All rights reserved. No reuse allowed without permission.

Tables

Table 1. Results for 4 common and 14 variants associated with conversion from AS to treatment in a genome-wide association analysis.

\begin{tabular}{|c|c|c|c|c|c|c|c|c|c|c|c|c|c|}
\hline \multirow[b]{2}{*}{ rsid } & \multirow[b]{2}{*}{ Chr } & \multirow[b]{2}{*}{$\begin{array}{r}\text { Gen } \\
\text { es }\end{array}$} & \multirow[b]{2}{*}{$\begin{array}{c}\text { Risk Allele } \\
/ \\
\text { ref allele }\end{array}$} & & \multicolumn{9}{|c|}{ HR $(95 \% \mathrm{Cl}), \mathrm{p}$-value } \\
\hline & & & & $\begin{array}{r}\text { RA } \\
\mathrm{F}\end{array}$ & \multicolumn{3}{|c|}{ Discovery European } & \multicolumn{2}{|c|}{$\begin{array}{c}\text { Replication } \\
\text { meta- } \\
\text { analysis }\end{array}$} & \multicolumn{4}{|c|}{ Combined meta-analysis } \\
\hline $\begin{array}{c}\text { rs771129 } \\
78\end{array}$ & 18 & $\begin{array}{c}A T P 8 B \\
1 \\
N E D D 4 \\
L^{a}\end{array}$ & $\mathrm{G} / \mathrm{C}$ & 0.048 & $\begin{array}{r}1.4 \\
1\end{array}$ & $\begin{array}{c}(1.23- \\
1.63)\end{array}$ & $\begin{array}{l}1.51 \\
\times 10^{-6}\end{array}$ & 2.24 & $\begin{array}{l}(1.38- \\
3.65)\end{array}$ & $\begin{array}{l}1.14 \\
\times 10^{-3}\end{array}$ & $\begin{array}{r}1 . \\
47\end{array}$ & $\begin{array}{c}(1.28- \\
1.68)\end{array}$ & $\begin{array}{l}3.26 \\
\times 10^{-8}\end{array}$ \\
\hline $\begin{array}{c}\text { rs } 558508 \\
37\end{array}$ & 18 & $\begin{array}{c}M C 4 R \\
\underset{a}{C D H 20}\end{array}$ & $A / G$ & 0.050 & $\begin{array}{r}1.4 \\
2\end{array}$ & $\begin{array}{c}(1.24- \\
1.63)\end{array}$ & $\begin{array}{l}3.43 \\
\times 10^{-7}\end{array}$ & 1.92 & $\begin{array}{c}(1.09- \\
3.36)\end{array}$ & 0.0232 & $\begin{array}{r}1 . \\
45\end{array}$ & $\begin{array}{c}(1.27- \\
1.65)\end{array}$ & $\begin{array}{l}4.03 \\
\times 10^{-8}\end{array}$ \\
\hline $\begin{array}{c}\text { rs } 178785 \\
33\end{array}$ & 19 & $\underset{1^{b}}{I L 12 R B}$ & $A / G$ & 0.651 & $\begin{array}{r}1.2 \\
3\end{array}$ & $\begin{array}{c}(1.14- \\
1.32)\end{array}$ & $\begin{array}{l}4.56 \\
\times 10^{-8}\end{array}$ & 0.94 & $\begin{array}{c}(0.75- \\
1.18)\end{array}$ & 0.582 & $\begin{array}{r}1 . \\
2\end{array}$ & $\begin{array}{c}(1.12- \\
1.28)\end{array}$ & $\begin{array}{l}4.86 \\
\times 10^{-7}\end{array}$ \\
\hline $\begin{array}{c}\text { rs748741 } \\
16\end{array}$ & 20 & $\begin{array}{c}\text { RBBP8 } \\
N L \\
\text { GATA5 } \\
a\end{array}$ & $\mathrm{~T} / \mathrm{G}$ & 0.028 & $\begin{array}{r}2.6 \\
7\end{array}$ & $\begin{array}{c}(1.94- \\
3.66)\end{array}$ & $\begin{array}{l}1.47 \\
\times 10^{-9}\end{array}$ & 1.23 & $\begin{array}{c}(0.93- \\
1.64)\end{array}$ & 0.146 & $\begin{array}{r}1 . \\
74\end{array}$ & $\begin{array}{l}(1.41- \\
2.15)\end{array}$ & $\begin{array}{l}3.14 \\
\times 10^{-7}\end{array}$ \\
\hline \multicolumn{14}{|l|}{$\begin{array}{l}\text { Rare } \\
\text { variants }\end{array}$} \\
\hline $\begin{array}{c}\text { rs665866 } \\
4\end{array}$ & 1 & $\begin{array}{c}P R D M 1 \\
6^{b}\end{array}$ & $A / G$ & 0.014 & $\begin{array}{r}5.1 \\
9\end{array}$ & $\begin{array}{c}(3.33- \\
8.09)\end{array}$ & $\begin{array}{l}3.55 \\
\times 10^{-13}\end{array}$ & 0.94 & $\begin{array}{c}(0.67- \\
1.33)\end{array}$ & 0.746 & $\begin{array}{r}1 . \\
79\end{array}$ & $\begin{array}{c}(1.37- \\
2.46)\end{array}$ & $\begin{array}{l}2.58 \\
\times 10^{-5}\end{array}$ \\
\hline $\begin{array}{c}\text { rs } 140461 \\
0\end{array}$ & 2 & $\begin{array}{c}\text { LINC01 } \\
101 \\
G L / 2^{a}\end{array}$ & $\mathrm{G} / \mathrm{A}$ & 0.012 & $\begin{array}{r}15 . \\
15\end{array}$ & $\begin{array}{c}(4.64- \\
49.5)\end{array}$ & $\begin{array}{l}6.69 \\
\times 10^{-6}\end{array}$ & 3.07 & $\begin{array}{c}(1.97- \\
4.79)\end{array}$ & $\begin{array}{l}7.84 \\
\times 10^{-7}\end{array}$ & $\begin{array}{r}3 . \\
74\end{array}$ & $\begin{array}{l}(2.47- \\
5.67)\end{array}$ & $\begin{array}{l}5.37 \\
\times 10^{-10}\end{array}$ \\
\hline $\begin{array}{c}\text { rs } 116419 \\
656\end{array}$ & 3 & $\begin{array}{c}\text { FAM86 } \\
D P \\
\text { MIR132 } \\
4^{a}\end{array}$ & $\mathrm{G} / \mathrm{A}$ & 0.010 & $\begin{array}{r}6.8 \\
9\end{array}$ & $\begin{array}{c}(4.03- \\
11.8)\end{array}$ & $\begin{array}{l}1.95 \\
\times 10^{-12}\end{array}$ & 0.96 & $\begin{array}{c}(0.47- \\
2.00)\end{array}$ & 0.923 & $\begin{array}{r}3 . \\
45\end{array}$ & $\begin{array}{c}(2.24- \\
5.32)\end{array}$ & $\begin{array}{l}2.06 \\
\times 10^{-8}\end{array}$ \\
\hline $\begin{array}{c}\text { rs } 472124 \\
3\end{array}$ & 7 & $\underset{1^{b}}{M A D 1 L}$ & $A / G$ & 0.010 & $\begin{array}{r}5.6 \\
5\end{array}$ & $\begin{array}{c}(3.26- \\
9.8)\end{array}$ & $\begin{array}{l}7 \\
\times 10^{-10}\end{array}$ & 0.78 & $\begin{array}{r}(0.5- \\
1.22)\end{array}$ & 0.28 & $\begin{array}{r}1 . \\
70\end{array}$ & $\begin{array}{l}(1.2- \\
2.39)\end{array}$ & $\begin{array}{l}2.6 \\
\times 10^{-3}\end{array}$ \\
\hline $\begin{array}{c}\text { rs113658 } \\
888\end{array}$ & 8 & $\underset{1^{b}}{\mathrm{MROH}}$ & $\mathrm{T} / \mathrm{C}$ & 0.011 & $\begin{array}{r}3.8 \\
6\end{array}$ & $\begin{array}{c}(2.60- \\
5.74)\end{array}$ & $\begin{array}{l}2.52 \\
\times 10^{-11}\end{array}$ & 1.22 & $\begin{array}{c}(0.84- \\
1.78)\end{array}$ & 0.305 & $\begin{array}{r}2 . \\
11\end{array}$ & $\begin{array}{l}(1.6- \\
2.77)\end{array}$ & $\begin{array}{l}9.04 \\
\times 10^{-8}\end{array}$ \\
\hline $\begin{array}{c}\text { rs } 115861 \\
550\end{array}$ & 9 & $V A V 2^{b}$ & $\mathrm{~T} / \mathrm{C}$ & 0.010 & $\begin{array}{r}7.5 \\
1\end{array}$ & $\begin{array}{c}(4.48- \\
12.6)\end{array}$ & $\begin{array}{l}2.03 \\
\times 10^{-14}\end{array}$ & 1.01 & $\begin{array}{c}(0.69- \\
1.48)\end{array}$ & 0.943 & $\begin{array}{r}2 . \\
05\end{array}$ & $\begin{array}{c}(1.51- \\
2.79)\end{array}$ & $\begin{array}{l}4.26 \\
\times 10^{-6}\end{array}$ \\
\hline $\begin{array}{c}\mathrm{rs} 375082 \\
7\end{array}$ & 10 & $E B F 3^{b}$ & $A / G$ & 0.011 & 2.4 & $\begin{array}{c}(1.79- \\
3.21)\end{array}$ & $\begin{array}{l}5.05 \\
\times 10^{-9}\end{array}$ & 1.78 & $\begin{array}{c}(1.04- \\
3.03)\end{array}$ & 0.035 & $\begin{array}{r}2 . \\
24\end{array}$ & $\begin{array}{c}(1.73- \\
2.89)\end{array}$ & $\begin{array}{l}8.29 \\
\times 10^{-10}\end{array}$ \\
\hline $\begin{array}{c}\text { rs } 285149 \\
69\end{array}$ & 11 & $\begin{array}{c}\text { TSPAN } \\
4^{b}\end{array}$ & $\mathrm{C} / \mathrm{T}$ & 0.011 & $\begin{array}{r}14 . \\
16\end{array}$ & $\begin{array}{c}(5.78- \\
34.7)\end{array}$ & $\begin{array}{l}6.69 \\
\times 10^{-9}\end{array}$ & 1.49 & $\begin{array}{l}(0.92- \\
2.39)\end{array}$ & 0.103 & $\begin{array}{r}2 . \\
44\end{array}$ & $\begin{array}{l}(1.6- \\
3.72)\end{array}$ & $\begin{array}{l}3.16 \\
\times 10^{-5}\end{array}$ \\
\hline rs563064 & 13 & $F 10^{c}$ & $A / G$ & 0.010 & $\begin{array}{r}34 . \\
03\end{array}$ & $\begin{array}{c}(10.4- \\
111)\end{array}$ & $\begin{array}{l}4.59 \\
\times 10^{-9}\end{array}$ & 2.2 & $\begin{array}{c}(1.45- \\
3.34)\end{array}$ & $\begin{array}{l}1.96 \\
\times 10^{-4}\end{array}$ & $\begin{array}{r}2 . \\
98\end{array}$ & $\begin{array}{c}(2.01- \\
4.41)\end{array}$ & $\begin{array}{l}4.89 \\
\times 10^{-8}\end{array}$ \\
\hline rs820198 & 17 & $\underset{5^{b}}{R E C Q L}$ & $\mathrm{~T} / \mathrm{C}$ & 0.010 & $\begin{array}{r}14 . \\
26\end{array}$ & $\begin{array}{c}(6.56- \\
31.0)\end{array}$ & $\begin{array}{l}2.03 \\
\times 10^{-11}\end{array}$ & 1.2 & $\begin{array}{c}(0.67- \\
2.17)\end{array}$ & 0.537 & $\begin{array}{l}2 . \\
97\end{array}$ & $\begin{array}{c}(1.86- \\
4.75)\end{array}$ & $\begin{array}{l}5.50 \\
\times 10^{-6}\end{array}$ \\
\hline $\begin{array}{c}\text { rs } 124526 \\
25\end{array}$ & 17 & $R F N G^{d}$ & $A / G$ & 0.011 & $\begin{array}{r}3.8 \\
4\end{array}$ & $\begin{array}{c}(2.65- \\
5.57)\end{array}$ & $\begin{array}{l}1.20 \\
\times 10^{-12}\end{array}$ & 1.03 & $\begin{array}{c}(0.68- \\
1.56)\end{array}$ & 0.878 & $\begin{array}{r}2 . \\
14\end{array}$ & $\begin{array}{c}(1.62- \\
2.82)\end{array}$ & $\begin{array}{l}6.84 \\
\times 10^{-8}\end{array}$ \\
\hline $\begin{array}{c}\text { rs590277 } \\
29\end{array}$ & 19 & $H C N 2^{b}$ & $A / G$ & 0.014 & $\begin{array}{r}2.0 \\
6\end{array}$ & $\begin{array}{c}(1.58- \\
2.68)\end{array}$ & $\begin{array}{l}7.24 \\
\times 10^{-8}\end{array}$ & 1.47 & $\begin{array}{c}(0.92- \\
2.34)\end{array}$ & 0.109 & $\begin{array}{r}1 . \\
90\end{array}$ & $\begin{array}{c}(1.51- \\
2.39)\end{array}$ & $\begin{array}{l}4.25 \\
\times 10^{-8}\end{array}$ \\
\hline $\begin{array}{c}\text { rs116837 } \\
676\end{array}$ & 19 & $\begin{array}{c}\text { MYAD } \\
M^{b}\end{array}$ & $\mathrm{~A} / \mathrm{G}$ & 0.011 & $\begin{array}{r}5.4 \\
2\end{array}$ & $\begin{array}{c}(3.00- \\
9.77)\end{array}$ & $\begin{array}{l}2.01 \\
\times 10^{-8}\end{array}$ & 1.72 & $\begin{array}{c}(1.17- \\
2.53)\end{array}$ & $\begin{array}{l}5.66 \\
\times 10^{-3}\end{array}$ & $\begin{array}{r}2 . \\
42\end{array}$ & $\begin{array}{c}(1.76- \\
3.34)\end{array}$ & $\begin{array}{l}7.34 \\
\times 10^{-8}\end{array}$ \\
\hline $\begin{array}{c}\text { rs } 560649 \\
12\end{array}$ & $x$ & $\begin{array}{c}\text { POF1B } \\
\text { MIR132 } \\
1^{a}\end{array}$ & $T / G$ & 0.010 & $\begin{array}{r}24 . \\
7\end{array}$ & $\begin{array}{l}(8.95- \\
68.3)\end{array}$ & $\begin{array}{l}6.13 \\
\times 10^{-10}\end{array}$ & 1.07 & $\begin{array}{c}(0.85- \\
1.36)\end{array}$ & 0.55 & $\begin{array}{r}1 . \\
26\end{array}$ & $(1-1.59)$ & 0.0475 \\
\hline
\end{tabular}

Chr, chromosome; Ref, reference; RAF = Risk allele frequency; HR, hazard ratio; CI, Confidence Interval. SNPs included here are those with association $P<5 \times 10^{-8}$ either in European discovery GWAS or combined meta-analysis of all samples.

In the Genes column

a Intergenic (genes are two flanking)

b Intronic

c Upstream

d UTR3 
6,324 patients genotyped at

CIDR, imputed to TOPMed

\section{Exclude patients with $<6$ months} follow up on AS

14 genome-wide significant SNPs

\section{5,936 patients remain for} analysis

(1)
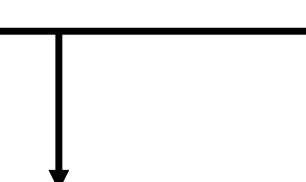

Discovery GWAS

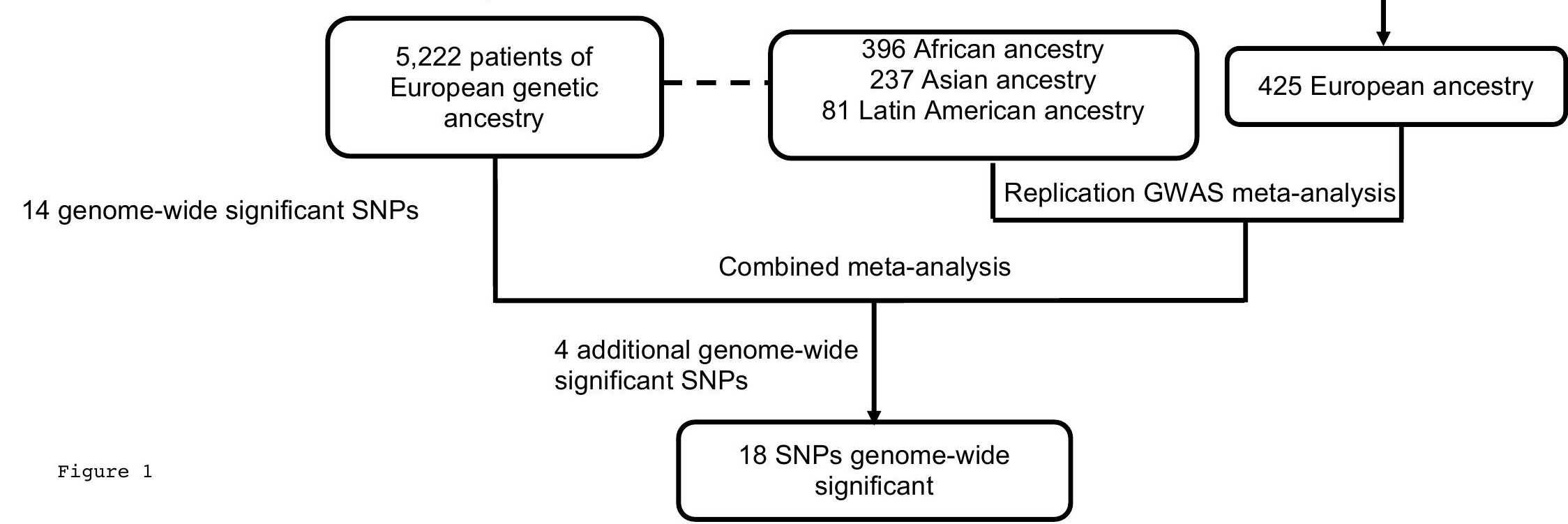

Exclude patients with $<6$ months follow up on AS

Exclude patients of non-

European genetic ancestry
596 patients genotyped at MD Anderson, imputed to 1000 Genomes 


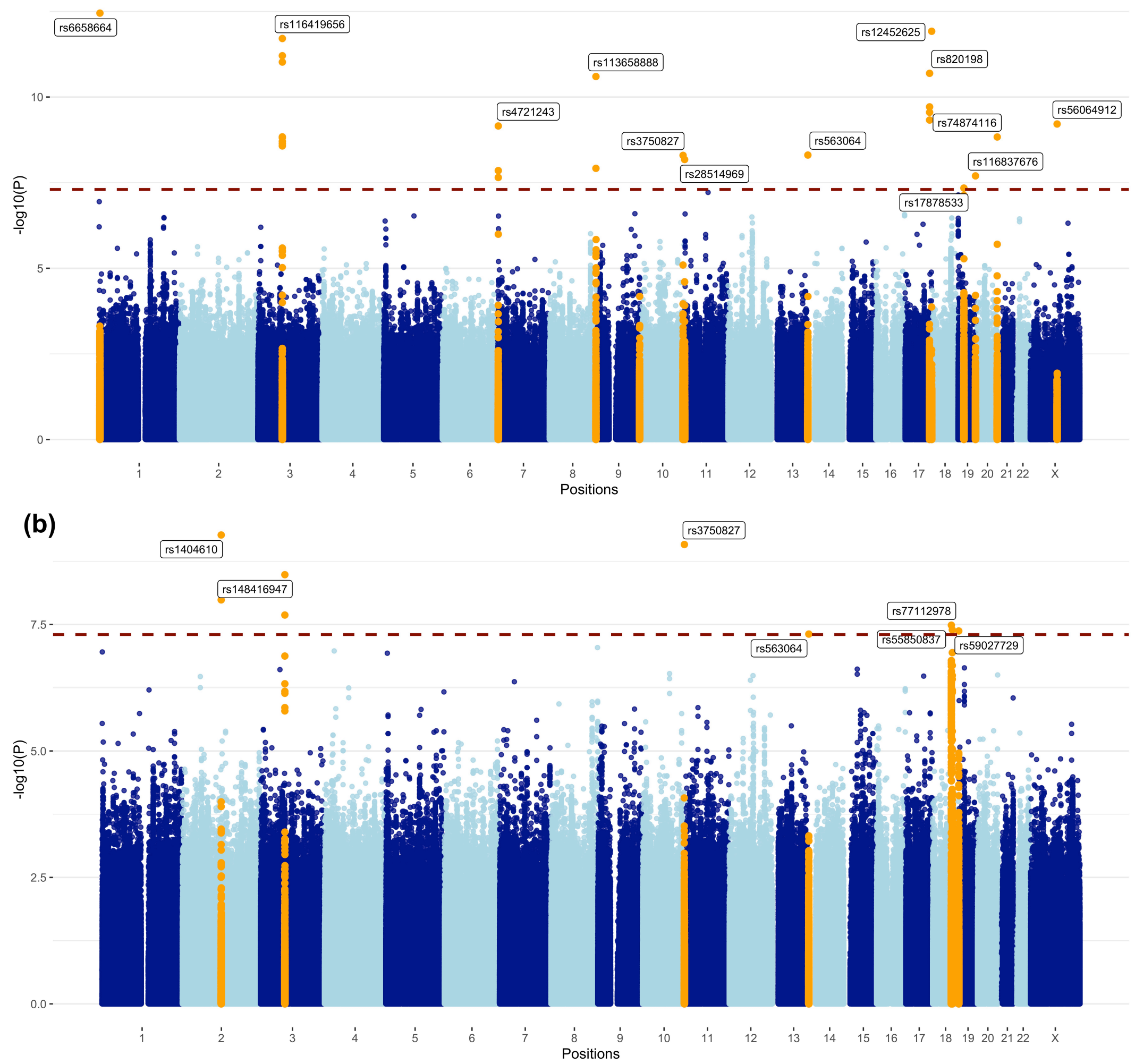


Figure 3

(a)
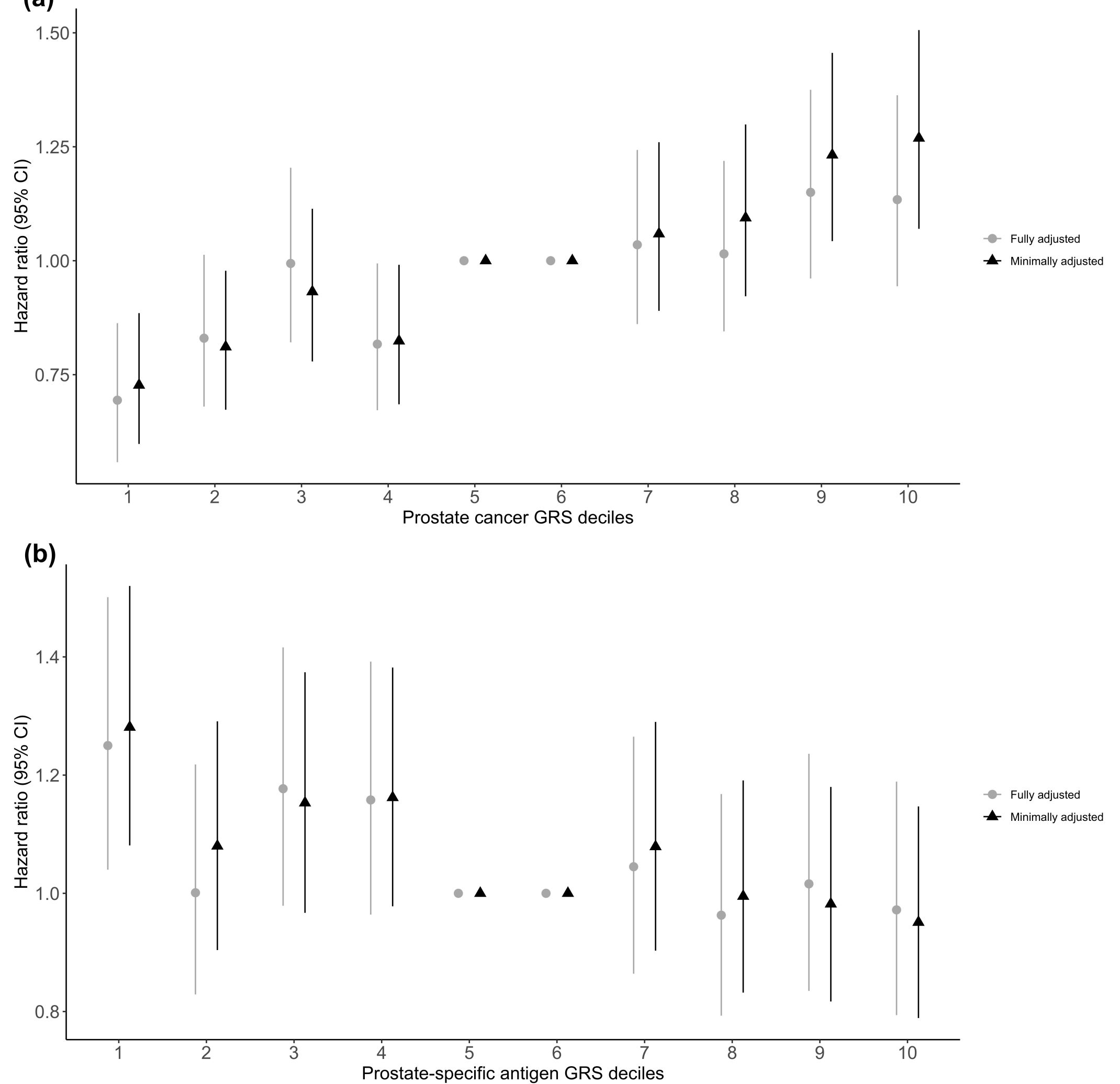


\section{Figure 4}

+ Low-Risk, Top Decile

- Intermediate-Risk, Top Decile

High-Risk, Top Decile

- Low-Risk, Bottom Decile

- Intermediate-Risk, Bottom Decile

High-Risk, Bottom Decile

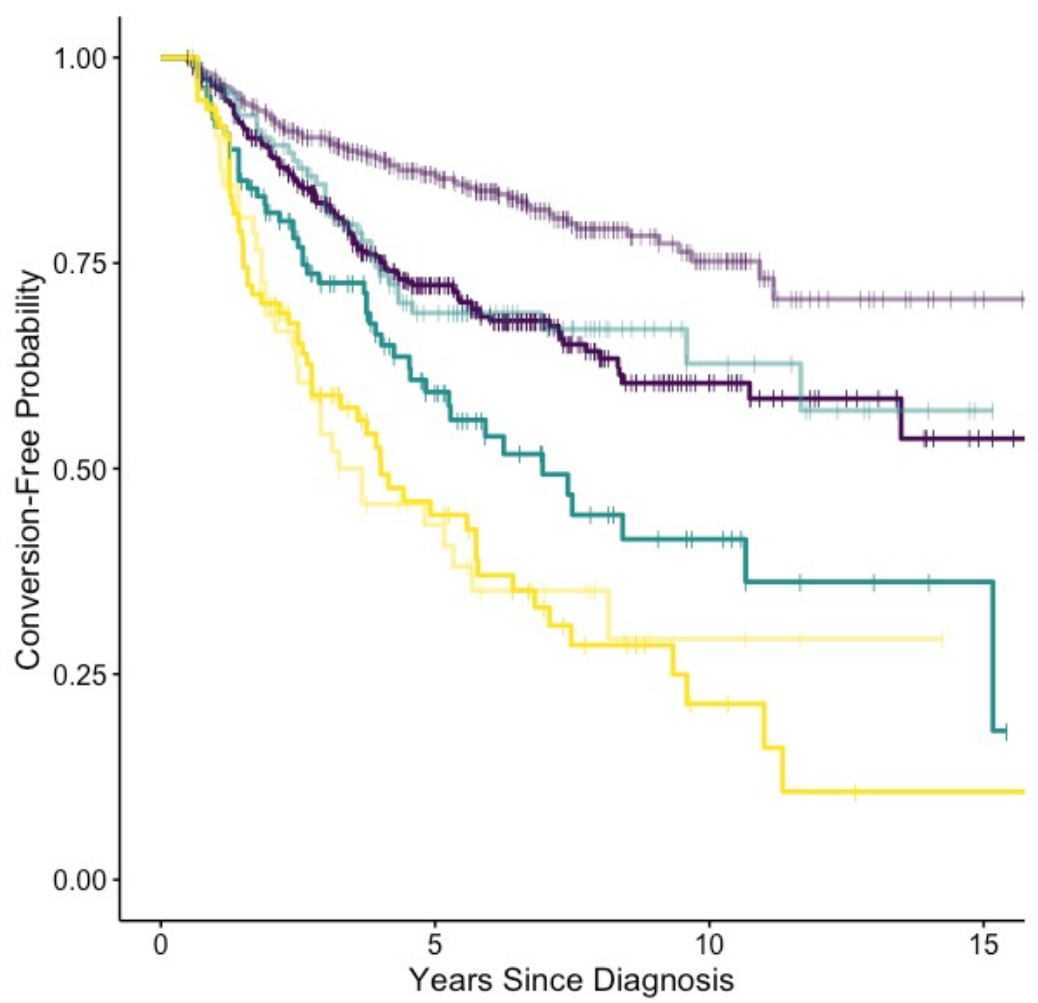

Number at risk

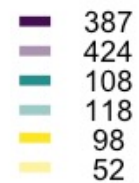

186
250
38
55
27
17

+ Low-Risk, Top Decile

- Intermediate-Risk, Top Decile

- High-Risk, Top Decile

+ Low-Risk, Bottom Decile

- Intermediate-Risk, Bottom Decile

High-Risk, Bottom Decile

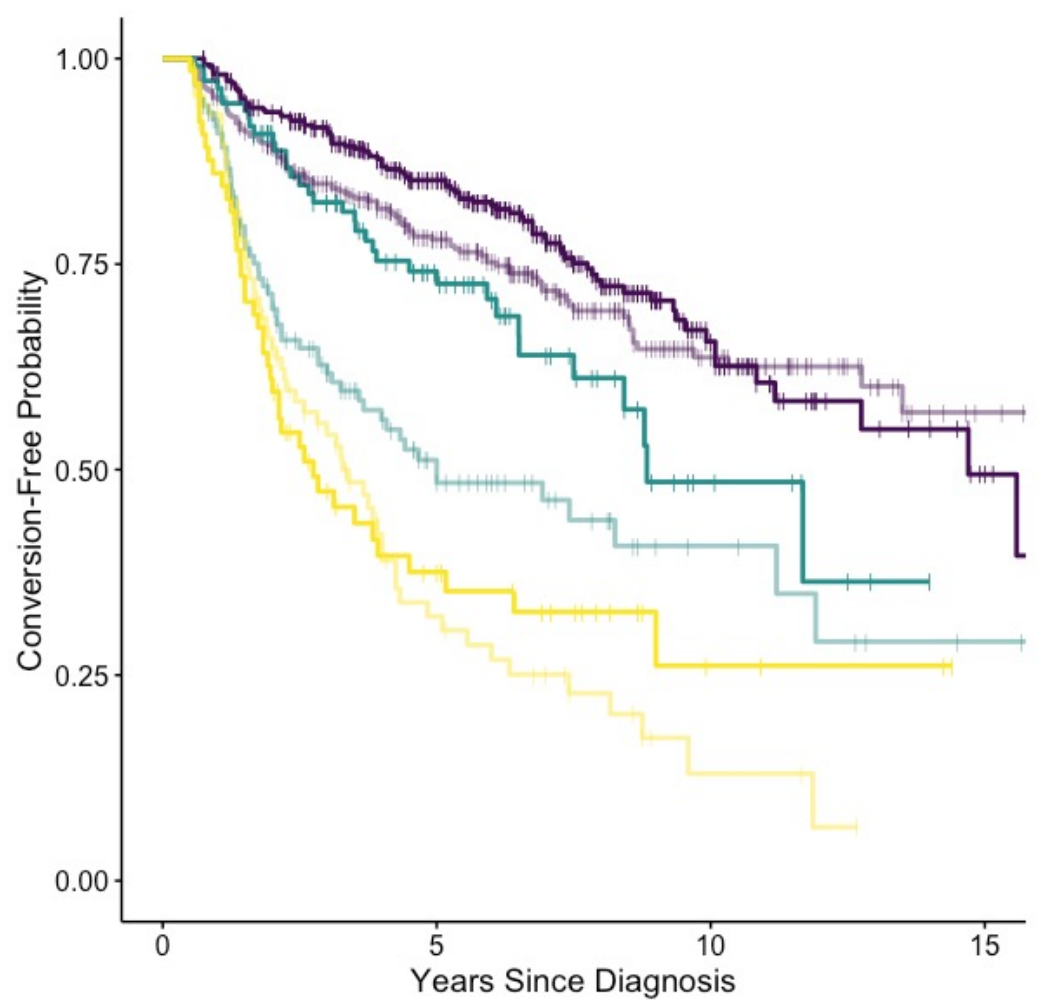

\section{Number at risk}

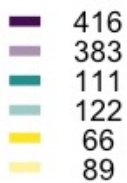

238
210
49
35
17
19

